Claudia Concer Viero Nora

\title{
ASSOCIAÇÃO ENTRE DOENÇA DE CROHN E INFECÇÃO POR MYCOBACTERIUM AVIUM PARATUBERCULOSIS EM UMA POPULAÇÃO BRASILEIRA
}

Tese apresentada à Sociedade Beneficente Israelita Brasileira Albert Einstein para obtenção do Título de Doutor em Ciências da Saúde.

São Paulo 


\section{Claudia Concer Viero Nora}

\section{ASSOCIAÇÃO ENTRE DOENÇA DE CROHN E INFECÇÃO POR MYCOBACTERIUM AVIUM PARATUBERCULOSIS EM UMA POPULAÇÃO BRASILEIRA}

Tese apresentada à Sociedade Beneficente Israelita Brasileira Albert Einstein para obtenção do Título de Doutor em Ciências da Saúde.

Orientador: Prof. Dr. Luiz Vicente Rizzo Coorientadora: Dra. Karina Inácio Ladislau de Carvalho 
$\mathrm{N} 822 \mathrm{c}$

Nora, Claudia Concer Viero

Associação entre doença de Crohn e infecção por Mycobacterium avium paratuberculosis em uma população brasileira / Claudia Concer Viero Nora. -- São Paulo, 2018.

ix, $36 \mathrm{f}$., il.

Tese (Doutorado) - Sociedade Beneficente Israelita Brasileira Albert Einstein. Instituto Israelita de Ensino e Pesquisa Albert Einstein. Programa de Pós-Graduação em Ciências da Saúde.

Título em inglês: Crohn's disease and its association with Mycobacterium avium paratuberculosis infection in a Brazilian population.

1. Doença de Crohn. 2. Bactérias gram-positivas. 3. Mycobacterium avium subsp. paratuberculosis.

NLM - WI 422

Elaborada pelo Sistema Einstein Integrado de Bibliotecas 
SOCIEDADE BENEFICENTE ISRAELITA BRASILEIRA ALBERT EINSTEIN

Coordenador do Curso de Pós-Graduação: Prof. Dr. Luiz Vicente Rizzo 


\section{Claudia Concer Viero Nora}

\section{ASSOCIAÇÃO ENTRE DOENÇA DE CROHN E INFECÇÃO POR MYCOBACTERIUM AVIUM PARATUBERCULOSIS EM UMA POPULAÇÃO BRASILEIRA}

Presidente da banca: Prof. Dr. Luiz Vicente Rizzo

BANCA EXAMINADORA

Membros titulares:

Dr. Ary Serpa Neto

Dr. Luís Fernando Aranha Camargo

Dra. Jane Oba

Membros suplentes:

Dr. Thiago Domingos Correa

Dra. Myrthes Anna Maragna Toledo Barros

Aprovada em: 28/02/2018. 


\section{Sumário}

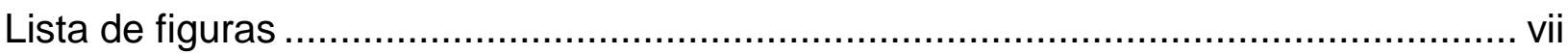

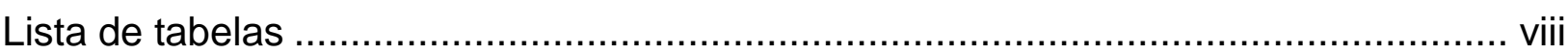

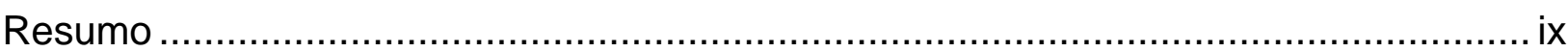

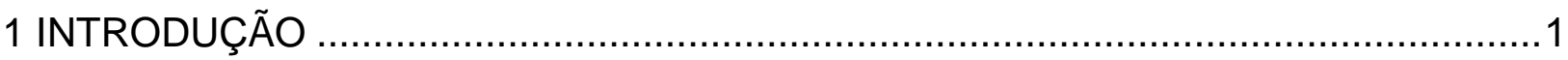

1.1 Mycobacterium avium paratuberculosis........................................................

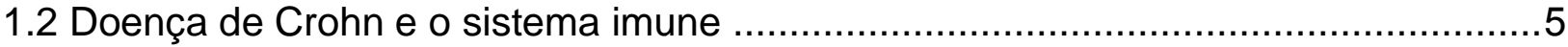

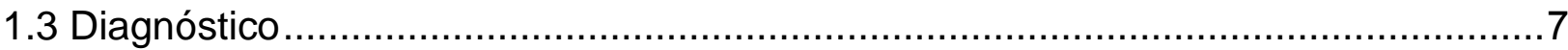

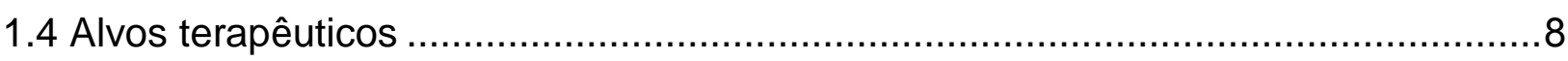

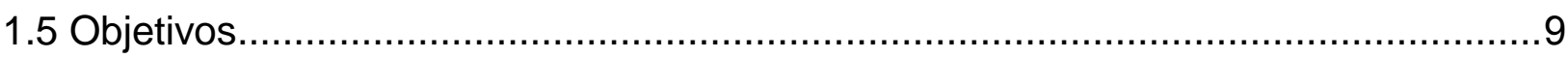

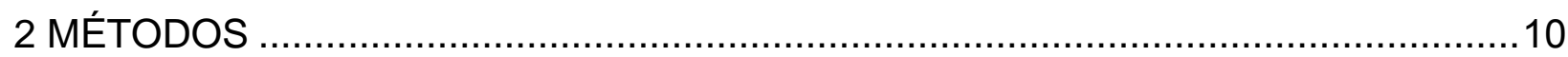

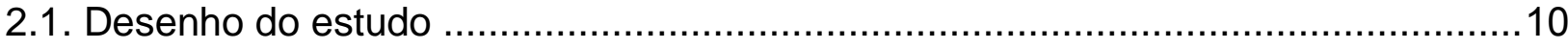

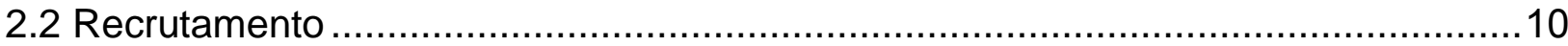

2.3 Coleta e processamento de material: sangue periférico ..................................11

2.4 Coleta e processamento de material: fezes................................................... 11

2.5 Tecido de mucosa e abscesso intestinal ......................................................... 12

2.6 Cultura de Mycobacterium avium subsp. paratuberculosis................................. 12

2.7 Dosagem de calprotectina ................................................................ 12

2.8 Hemograma, coagulograma e ensaios bioquímicos ........................................ 13

2.9 Extração de DNA de fezes .......................................................................... 13

2.10 PCR em tempo-real para detecção de Mycobacterium avium subsp. paratuberculosis (fezes e tecido) ......................................................................... 13

2.11 Cálculo do índice de atividade da doença ................................................ 14

2.12 Aspectos éticos .................................................................................... 14

2.13 Análise estatística....................................................................... 14

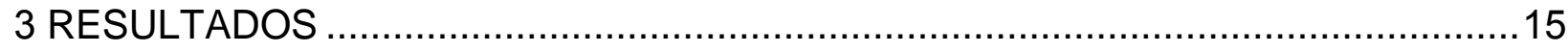

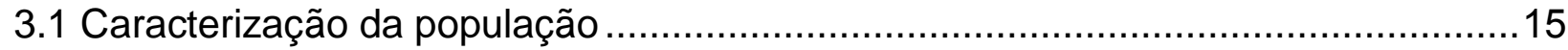

3.2 Índice de atividade da doença e regime terapêutico ....................................... 15

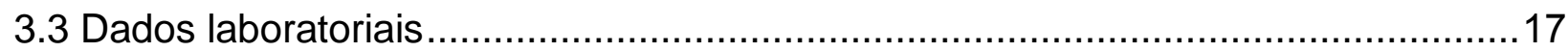

3.4 Tecido de mucosa e abscesso intestinal ....................................................... 19

3.5 Padronização do protocolo de PCR em tempo-real ........................................19

3.6 PCR em tempo-real ........................................................................... 21 


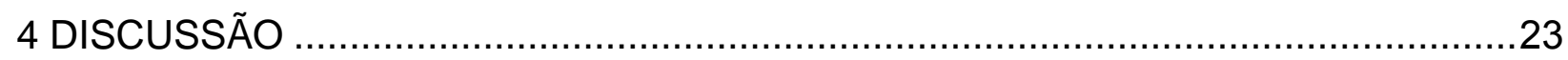

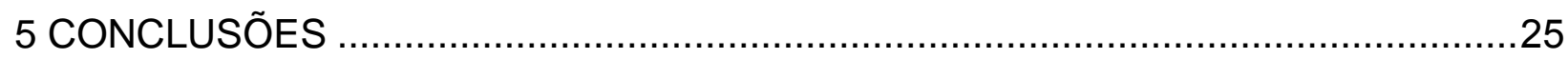

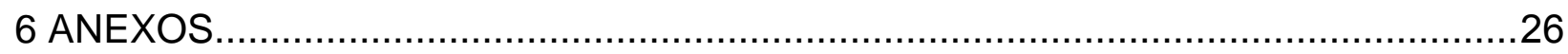

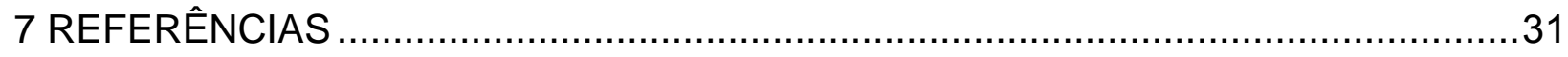

Abstract 


\section{Lista de figuras}

Figura 1. Fatores genéticos e ambientais influenciam a composição da microbiota

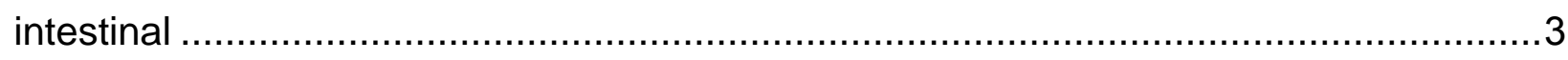

Figura 2. Representação do sistema imune da mucosa do trato gastrointestinal ..........6 Figura 3. Fragmento de Mycobacterium avium subsp. paratuberculosis sintética inserida em pMA-T. 19

Figura 4. Sensibilidade do teste de PCR em tempo real nas diferentes concentrações do plasmídio . 20

Figura 5. Representação da curva de Melting nas diferentes concentrações de plasmídio 21

Figura 6. Resultado da amplificação de DNA extraído de fezes de pacientes portadores de doença de Crohn 21

Figura 7. Resultado da amplificação de DNA extraído de fezes de voluntários sem doença (controles) 22

Figura 8. Resultado da amplificação de DNA extraído de tecido retirado de colectomia prévia de pacientes com DC. .22 


\section{Lista de tabelas}

Tabela 1. Comparação entre os grupos quanto a gênero e idade ..............................15

Tabela 2. Grau de Atividade da doença de Crohn no grupo de pacientes ................... 16

Tabela 3. Relação entre tipo de tratamento e Índice de Atividade da Doença.............16

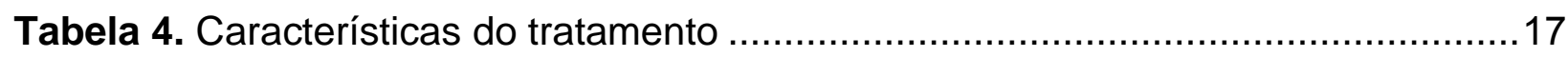

Tabela 5. Dados de testes laboratoriais .............................................................. 17

Tabela 6. Diferentes concentrações do plasmídio e o número de cópias contido em cada concentração 20 


\section{Resumo}

Introdução: Por muito tempo tem se buscado evidências de uma relação causal entre infecção por Mycobacterium avium subsp. paratuberculosis e a doença de Crohn, porém esta associação ainda não foi definida. Apesar de muitos estudos já demonstrarem uma correlação positiva entre a doença e uma possível infecção por este patógeno, não está evidente a relação destes achados com as características da população estudada. Objetivos: Caracterizar clinicamente a população de pacientes diagnosticados com Doença de Crohn e verificar a presença de Mycobacterium avium subsp. paratuberculosis em fezes de pacientes e controles saudáveis. Métodos: Amostras de sangue e fezes de 52 pacientes e 43 controles saudáveis foram coletadas. Foram realizados testes clínicos e exames laboratoriais além da extração de DNA das fezes obtidas. A presença de Mycobacterium avium subsp. paratuberculosis foi avaliada através da técnica de PCR em tempo real. Resultados: Não encontramos evidencias de Mycobacterium avium subsp. paratuberculosis nas amostras de fezes estudadas. Verificamos valores significativamente aumentados de calprotectina fecal no grupo de pacientes $(p<0,001)$. A maior parte dos pacientes estudados possui um regime terapêutico bem estabelecido (88,5\%) e está em tratamento a mais de um ano. Conclusões: As características da população estudada podem interferir na análise da presença de Mycobacterium avium subsp. paratuberculosis em pacientes com Doença de Crohn. Critérios específicos de recrutamento são necessários para fazer esta análise. 


\section{INTRODUÇÃO}

O trato gastrointestinal é composto por uma camada simples de células epiteliais que separa o lúmen intestinal dos tecidos convencionais e o sistema imune. ${ }^{(1,2)}$ É exposto constantemente a antígenos do meio ambiente e é colonizado por diferentes tipos de bactérias comensais. Portanto o sistema imune é confrontado com a difícil tarefa de aumentar a tolerância para antígenos inofensivos e também proteger contra patógenos invasores.

Uma resposta inflamatória inapropriada e contínua frente à microbiota comensal, caracteriza as Doenças Inflamatórias Intestinais (DII). Nessas doenças, percebe-se uma liberação espontânea de citocinas pró-inflamatórias as quais alteram a homeostase da mucosa. ${ }^{(3)}$ É caracterizada por uma inflamação crônica do trato gastrointestinal que atinge com maior prevalência a região do cólon proximal e intestino delgado distal, sendo que os sintomas mais comuns incluem dor abdominal, diarreia e perda de peso ocasionando danos progressivos a mucosa do intestino. ${ }^{(4)} \mathrm{E}$ uma doença imprevisível com sintomas potencialmente debilitantes e que tem seu início da adolescência ou início da idade adulta. ${ }^{(5)}$

Dentre as DII, a Doença de Crohn (DC) tem recebido maior atenção devido ao aumento de sua incidência nos últimos anos. Em algumas áreas dos Estados Unidos esta incidência chega em torno de 7 a 8 milhões de casos por ano ${ }^{(6)}$ e na Europa vem crescendo o número de adultos diagnosticados. ${ }^{(7)}$ Já no Brasil, um único estudo feito na cidade de São Paulo, demonstrou um predomínio da doença na raça branca $(91.07 \%)$ e urbana $(90.51 \%)$, com incidência de 3.5 e prevalência de 5.62 casos novos diagnosticados por ano. ${ }^{(8)}$

Por esta razão, vêm sendo tratadas em muitos países como um problema de saúde pública, dado principalmente ao fato de acometer uma população que necessitará, por um grande período de tempo, de cuidados médicos extensos e de alto custo. $O$ aumento principal tem sido observado em população jovem ( $<20$ anos) com suposta falta de predisposição a fatores ambientais que possam estabelecer uma imunidade defensiva. Assim, uma vez expostos a novos e diferentes fatores ambientais, esses indivíduos podem desenvolver morbidades autoimunes, como as DII. ${ }^{(9)}$

Mesmo com o crescente número de pessoas afetadas pela doença, 
poucos têm sido os avanços para se conter o crescimento exponencial. A maior parte dos tratamentos desenvolvidos tem se voltado para conter os sintomas e melhorar a qualidade de vida do paciente, sendo poucos os estudos voltados na descoberta da causa da doença.

Alguns grupos de pesquisadores vêm sugerindo que a inflamação pode representar uma resposta compensatória a uma variedade de pequenos defeitos na imunidade inata da mucosa. Estas deficiências podem ser responsáveis por alterações na microbiota intestinal (disbiose) que, juntamente com danos multifatoriais da barreira intestinal, podem facilitar a translocação bacteriana para a lâmina própria e o engajamento de células inflamatórias. ${ }^{(10)}$ Esta disbiose pode ainda estar sendo influenciada por suscetibilidade genética atrelada a fatores ambientais, o que levam a uma alteração da microbiota intestinal. A proporção de bactérias protetoras/prejudiciais ativam uma cascata inflamatória que leva à DC em organismos geneticamente suscetíveis, mas mantêm a homeostase da mucosa em indivíduos normais (Figura 1). ${ }^{(11)}$ 


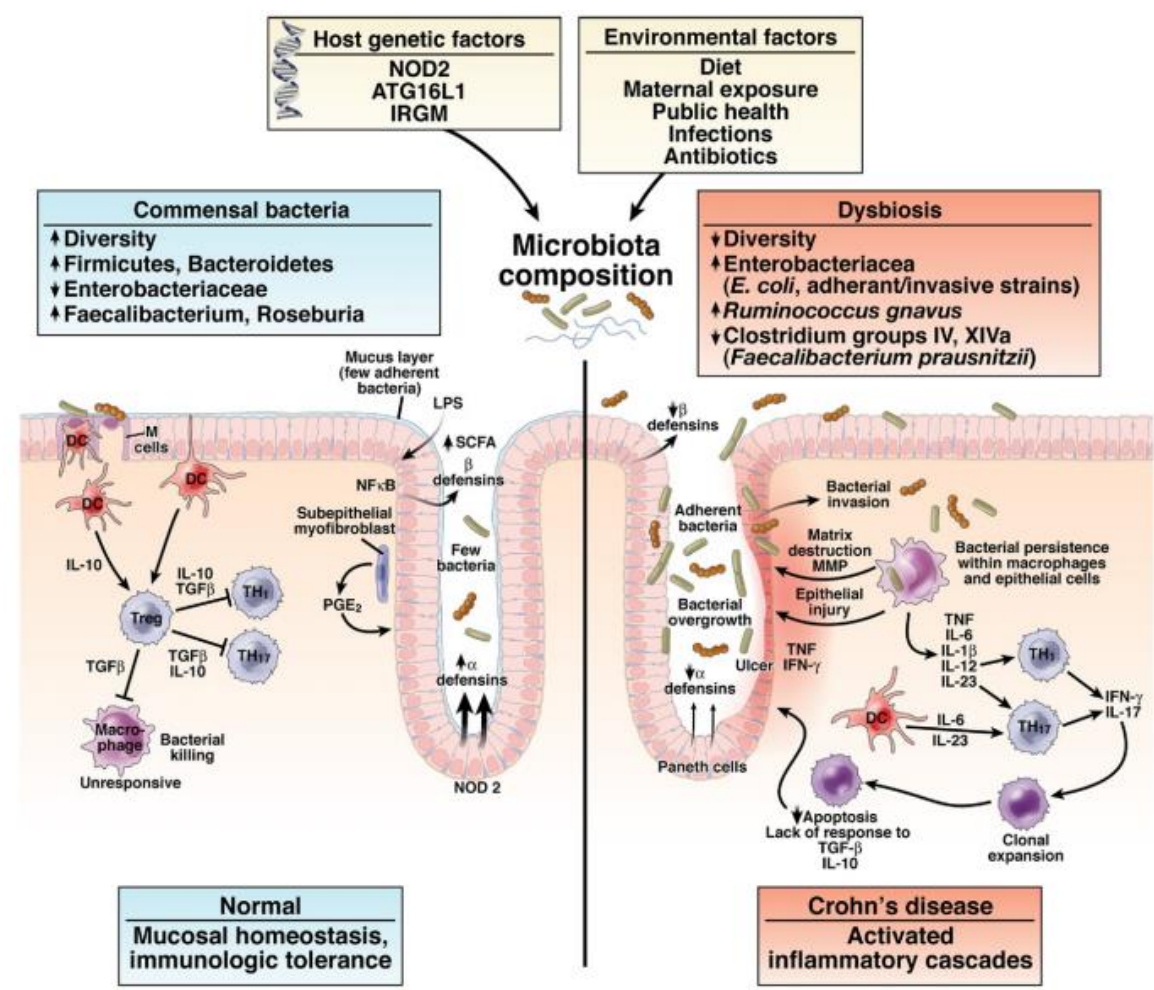

Fonte: Sartor RB. Genetics and environmental interactions shape the intestinal microbiome to promote inflammatory bowel disease versus mucosal homeostasis. Gastroenterology. 2010;139(6):1816-9. Figure 1, Genetic and environmental factors influence intestinal microbiota composition, which has an overall protective role in normal hosts, but containsan abnormal ratio of beneficial and aggressive bacterial species (dysbiosis) in Crohn's disease patients. This ratio of protective/ detrimental bacteria drivesactivated inflammatory cascades leading to Crohn's disease in genetically susceptible hosts and maintains mucosal homeostasis in normal subjects; p. 1817. ${ }^{(11)}$

Figura 1. Fatores genéticos e ambientais influenciam a composição da microbiota intestinal

Atualmente, mais de 25 doenças ou síndromes foram associadas à alteração da microbiota intestinal. ${ }^{(12)}$ Embora a etiopatologia da DC, ainda não esteja clara, já existem dados abundantes que confirmam a importância da microbiota intestinal no processo inflamatório que existe nas DII. ${ }^{(13,14)}$

A translocação bacteriana representa um possível mecanismo de permeabilidade epitelial alterada, característico da DC. Além disso, estudos preliminares mostram que as bactérias estão mais frequentes em tecido adiposo mesentérico e nódulos linfáticos mesentéricos de pacientes com DC quando comparados a pessoas sem diagnóstico da doença. ${ }^{(15)} \mathrm{O}$ interesse em se investigar uma origem infecciosa para esta doença tem sido debatido há muito tempo como uma possível causa da DC. ${ }^{(16)}$ Apesar de ainda não terem sido identificadas bactérias específicas que desencadeiam uma resposta imune descontrolada que contribuam 
para a patogênese da DC, observações feitas por Chiodini et al, identificaram culturas aparentemente idênticas de Mycobacterium avium paratuberculosis (MAP) em três pacientes com diagnóstico da doença. ${ }^{(17)}$ Porém, ainda não esta claro se uma possível infecção por MAP pode ser caracterizada como a causa da doença ou se pacientes com DC estariam mais suscetíveis a infecções bacterianas como a paratuberculose.

Uma análise da literatura sobre a patologia da DC e uma possível infecção por MAP sugere que a bactéria pode infectar diretamente células endoteliais e adipócitos, permitindo sua proliferação, causando obstrução focal dentro de vasos já existentes (incluindo formação de granulomas), desenvolvendo novos vasos (neoangiogênese e linfoangiogênese) e o chamado creeping fat do mesentério, que é uma característica patológica particular da DC e que tem sido observada também na doença bovina de Johne's, a qual é causada por infecção por MAP. ${ }^{(18)}$

A principal característica da MAP que a distingue dos demais microrganismos que possam estar relacionados com a causa da DC, é a sua habilidade em causar inflamação crônica intestinal verificada em uma ampla gama de tipos histopatológicos em diferentes espécies de animais, incluindo primatas. ${ }^{(19)}$

Consolidando o envolvimento de um patógeno como gatilho para a doença, estudos envolvendo a análise genética de pacientes com DII, mostraram que a maioria das evidências relacionadas a eventuais genes causais, apontam para um papel essencial da defesa do hospedeiro contra uma infecção. ${ }^{(20)}$ Adicionado a isso, um estudo de meta-análise concluiu que existe uma associação específica entre a presença de anticorpos anti-MAP e a DC. ${ }^{(21)}$

\subsection{Mycobacterium avium paratuberculosis}

A MAP é um bacilo fracamente Gram positivo, intracelular, patógeno obrigatório, de crescimento lento e parede celular espessa composta principalmente por lipídios. Esta micobactéria é a causadora da Doença de Johne's, uma enterite crônica bovina, que apresenta similaridades clínicas e histopatológicas com a $\mathrm{DC}^{(16,22,23)}$ mesmo havendo discussões conflitantes sobre seu possível papel na

doença. ${ }^{(24)}$ Além disso, um estudo de meta-análises confirmou que a presença de MAP em pacientes com a doença é maior quando comparados com indivíduos saudáveis. ${ }^{(25)}$ 
A MAP possui a capacidade de sobreviver em vegetais fertilizados em estrume contaminado, em água e carne crua ${ }^{(26)}$ podendo também ser facilmente isolada do leite, ${ }^{(27-29)}$ cujo consumo pode ser uma via potencial de transmissão para os seres humanos.

Apesar de alguns estudos indicarem que não há relação absoluta entre MAP e $D C{ }^{(30,31)}$ uma proporção de crianças em estágios iniciais da doença contém MAP ou material genômico de MAP no sangue ou tecido intestinal. ${ }^{(32)}$ No entanto, esta micobactéria pode ser isolada a partir de amostras de fezes de indivíduos saudáveis ou que apresentam doenças não relacionadas, indicando uma susceptibilidade geral dos seres humanos à infecção por esta micobactéria. ${ }^{(33)}$

Em contrapartida, estudos recentes têm mostrado alta prevalência de MAP em pacientes com DC de diferentes etnias ${ }^{(34-36)}$ sendo que a ausência de DNA micobacteriano em alguns pacientes com a doença poderia ser explicada pelo fato de que diferentes populações bacterianas, estariam localizadas em regiões intestinais distintas $^{(34)}$ dificultando assim sua verificação.

\subsection{Doença de Crohn e o sistema imune}

As células do sistema imunológico, como macrófagos, células dendríticas, linfócitos $T$ e linfócitos $B$, juntamente com fatores como a microbiota residente, o peristaltismo, a produção de muco e substâncias antimicrobianas produzidas pelas células intestinais, atuam em conjunto para proporcionar o equilíbrio do ambiente intestinal.

A microbiota do intestino contribui para a proteção do sistema imune intestinal e possui um papel importante na manutenção da homeostasia através da modulação do sistema inato e adaptativo.

O Sistema GALT (tecido linfoide associado ao intestino) que compreende as placas de Peyer e os linfonodos mesentéricos são os principais locais de indução de resposta imune, sendo a lâmina própria e a camada epitelial os locais efetores. Em conjunto, formam os principais componentes do sistema imunológico intestinal (Figura 2). ${ }^{(37)}$ 


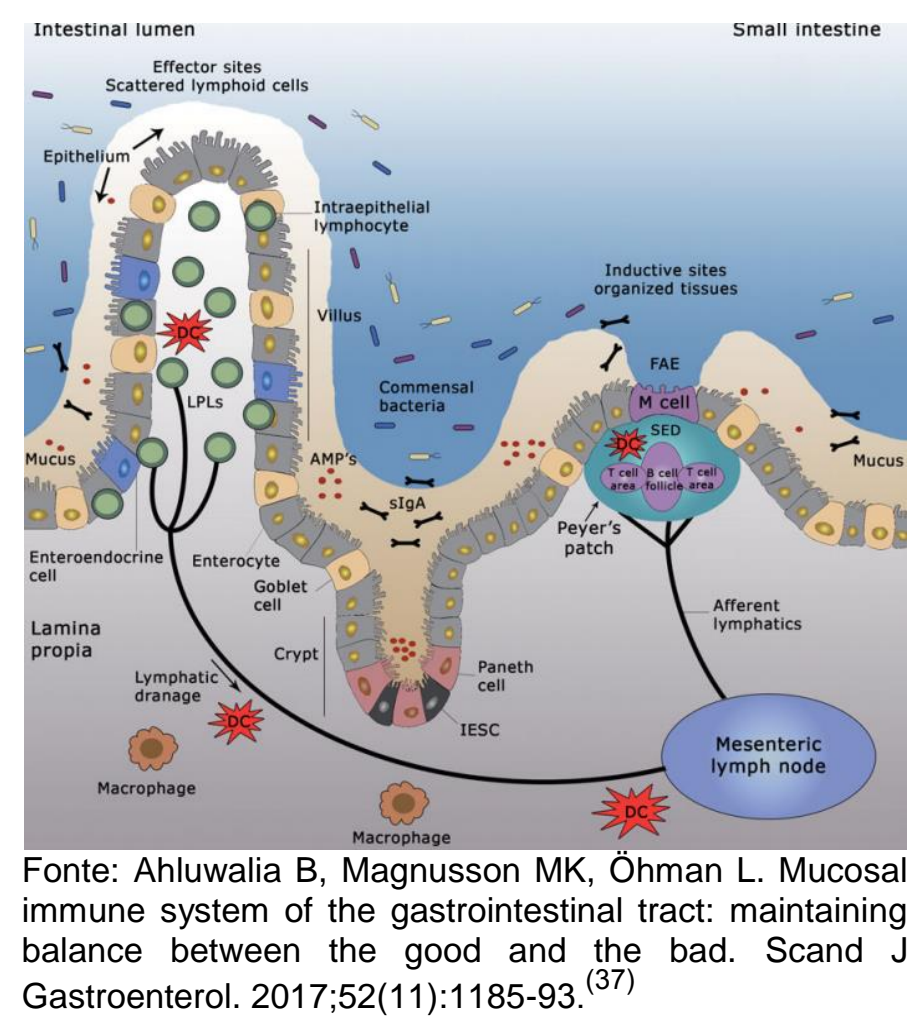

Figura 2. Representação do sistema imune da mucosa do trato gastrointestinal

$\mathrm{Na}$ imunopatogênese básica da DC verifica-se o envolvimento destas células do sistema imune intestinal associados com o recrutamento e ativação de citocinas inflamatórias, como interleucina 6 , interleucina 10, Interferon gama e Fator de Necrose Tumoral alfa (TNF- $\alpha){ }^{(38)}$

As células $T$ reguladoras, um tipo celular importante na manutenção da homeostasia, servem como protetoras contra o desenvolvimento de doenças autoimunes devido a sua habilidade de suprir células efetoras, mostrando até mesmo serem capazes de promover a cura do processo inflamatório em modelos murinos de colite. ${ }^{(39,40)}$

Um estudo recente mostrou uma prevalência de células $T$ responsivas a microbiota da mucosa intestinal. Neste ambiente, estas células mostraram um repertório TCRV $\beta$ diverso estimulando respostas inflamatórias pelo epitélio intestinal e células estromais. O mais interessante neste estudo, é que as células T de pacientes com DIl expressaram altas quantidade de IL-17A e as T CD4+ mostraram-se funcionalmente alteradas durante a patogênese da doença. ${ }^{(41)}$

Nas fezes e dialisados retais de pacientes diagnosticados com a doença tem se observado o aumento da secreção, de uma variedade de mediadores 
pró-inflamatórios, sendo a TNF-a, umas das principais citocinas envolvidas nesse processo $^{(42-44)}$ por ter um papel central na cascata inflamatória que caracteriza a inflamação intestinal crônica. ${ }^{(45)}$ É uma citocina de $17 \mathrm{kD}$ não glicosilada produzida principalmente por monócitos, macrófagos e células T ativadas. Após sua secreção, do qual é o resultado da clivagem do sinal de peptídeo por uma metaloproteinase, ela é secretada como um trimero bioativo de $51 \mathrm{kD}$. Quando não clivada esta pode ser ativada pelo contato de célula a célula, desde que a célula apresente os receptores para TNF- $\alpha$ (TNFR-1 ou TNFR-2). ${ }^{(46)}$

Atualmente as terapias anti-TNF têm sido a primeira opção dos especialistas que buscam atingir de forma eficaz a remissão da DC.

\subsection{Diagnóstico}

A DC, assim como as demais DII, são de diagnóstico complexo, o que exige a atuação de profissionais experientes, vistos que os sintomas são comuns entre as diferentes formas. Segundo as recomendações da Organização PanAmericana de Crohn e Colite, para um diagnóstico correto são necessários: avaliação física, testes laboratoriais (hemograma, teste de hemossedimentação (VHS), Proteína C-reativa (PCR), albumina, ferro, ferritina e calprotectina fecal); exclusão de HIV positivo, tuberculose e demais patologias, íleo colonoscopia e exames de imagem (ultrasom abdominal, ressonância magnética e trânsito intestinal). ${ }^{(47)}$ Sendo importante salientar que o diagnóstico somente poderá ser estabelecido por uma combinação não estritamente definida de apresentação clínica, aparência endoscópica, radiologia, histologia, achados cirúrgicos e sorologia. ${ }^{(48)}$

Dentre os testes diagnósticos, a calprotectina fecal é um dos exames com melhor eficácia para 0 monitoramento da atividade da doença, ${ }^{(49)}$ mostrando sensibilidade e especificidade de 89 e $79 \%$ respectivamente. ${ }^{(50)}$ A calprotectina é uma proteína citosólica neutrofílica de ligação ao cálcio e zinco que pode ser detectada nas fezes em proporção ao grau de inflamação intestinal. ${ }^{(51)}$ 


\subsection{Alvos terapêuticos}

Atualmente o uso de terapia biológica é utilizado como a melhor opção terapêutica para pacientes em atividade da DC. Os anticorpos monoclonais antiTNF estão entre a primeira linha de escolha terapêutica e compreendem as drogas infliximabe, adalimumabe e certolizumab pegol. Vários ensaios clínicos randomizados e controlados têm demonstrado a eficácia destes agentes na indução e manutenção da remissão da DC. . $^{(2-56)}$

Apesar dos medicamentos biológicos terem sido, com sucesso, cada vez mais utilizados no tratamento da DC e representarem hoje, uma das mais promissoras armas terapêuticas a ser utilizadas por pacientes com esta patologia, um grande número de pacientes não têm se beneficiado de seu uso. Estudos mostram que $50 \%$ dos pacientes que utilizam infliximabe, por exemplo, terão perda de resposta após dois anos de uso. ${ }^{(57)}$ Ocorre que toda droga biológica, pela sua própria natureza, favorece o desenvolvimento de anticorpos pelo usuário e, como consequência, a diminuição da sua eficácia terapêutica ao longo dos anos. Os anticorpos produzidos contra o biológico inativam os mesmos, diminuindo suas concentrações plasmáticas e, portanto, a sua eficácia. ${ }^{(58-61)}$

Por conta disso, medicações convencionais como prednisona e imunomoduladores como a azatioprina e 6-mercaptopurina são empregadas em conjunto com os anticorpos monoclonais para pacientes com fraca resposta terapêutica. ${ }^{(62)}$ Porém, o efeito imunossupressor ocasionado pelo uso destas drogas tem sido associado ao aparecimento de efeitos colaterais que tornam o manejo da doença mais complexo. ${ }^{(63-66)}$

Visando tratamentos com maior índice de remissão e controle do processo inflamatório em longo prazo, indústrias investem em desenvolvimento de drogas com diferentes enfoques terapêuticos. Diferente do que se tem trabalhado até hoje, ou seja, bloquear citocinas envolvidas no processo inflamatório, estudos clínicos randomizados, fase 3 , utilizando antibióticos anti-MAP para o tratamento da DC podem ser encontrados no clinical trial em fase de recrutamento. Estes estudos utilizam a droga RHB-104, considerada uma nova geração de tríplice de antibióticos (claritromicina, clofazimina e rifabutina) que mostrou indícios de ser um regime terapêutico mais eficaz para tratar DC associadas à infecção por MAP. ${ }^{(67)}$ 
No entanto, as diretrizes de tratamento atuais para DC não incluem terapia anti-micobacteriana específicas para MAP. ${ }^{(47)}$ Além disso, suprimir a resposta imune inflamatória anormal ao usar vários medicamentos anti-inflamatórios e biológicos, não mostram nenhum efeito significativo na erradicação de organismos microbianos como o MAP. ${ }^{(68)}$

A partir disso, tem se questionado se a MAP poderia ser o gatilho desencadeador de uma desregulação da resposta imune na DC. ${ }^{(23,24,69)}$ Devido a natureza incerta da doença atrelado a falta de um diagnóstico clínico conclusivo, percebe-se a necessidade de buscar novas informações e relações entre a infecção por MAP, para assim propor novas alternativas terapêuticas.

\subsection{Objetivos}

1. Caracterizar clinicamente a população de pacientes diagnosticados com Doença de Crohn;

2. Estabelecer um protocolo de extração e qualificação de Mycobacterium avium subsp. paratuberculosis em amostras de fezes e tecidos de pacientes acometidos pela doença;

3. Verificar a presença de Mycobacterium avium subsp. paratuberculosis em fezes de pacientes e voluntários sem doença. 


\section{MÉTODOS}

\subsection{Desenho do estudo}

Estudo prospectivo, aleatorizado, com inclusão de pacientes com diagnóstico confirmado de DC e voluntários saudáveis.

\subsection{Recrutamento}

O recrutamento foi realizado a partir do interesse voluntário dos pacientes mediante a divulgação do estudo no site do hospital. Os interessados foram selecionados a partir da análise de exames prévios (colonoscopia, imagens e testes laboratoriais) que identificam o diagnóstico de DC, respeitando os critérios de inclusão estabelecidos e controles sem doenças crônicas diagnosticadas. Avaliação médica foi realizada e amostras de sangue e fezes foram coletadas de todos os indivíduos que aceitaram fazer parte do estudo a partir da assinatura do Termo de Consentimento Livre e Esclarecido (TCLE). Os mesmos procedimentos foram realizados para recrutamento dos voluntários sem a doença que foram referenciados como Grupo Controle.

- Critérios de inclusão Grupo Pacientes:

- Idade igual ou superior a 18 anos completos;

- Indivíduos com sorologia negativa para: HIV1-2; HTLV1/2; sífilis; Hepatite-C (HCV) e Hepatite-B (HBV);

- Confirmação de diagnóstico de DC através de exames laboratoriais e de imagem;

- Pacientes em tratamento vigente para DC.

- Critérios de exclusão Grupo Pacientes:

- Outras doenças crônicas diagnosticadas;

- Diagnóstico ainda não confirmado de DC.

- Critérios de inclusão Grupo Controle: 
- Idade igual ou superior a 18 anos completos;

- Indivíduos com sorologia negativa para: HIV1-2; HTLV1/2; sífilis; HCV e HBV;

- Ausência de doenças crônicas;

- Critérios de exclusão Grupo Controle:

- Alterações clínicas nos exames realizados.

\subsection{Coleta e processamento de material: sangue periférico}

Foram coletados $60 \mathrm{~mL}$ de sangue periférico por punção venosa em membro superior, após cuidadosa assepsia local. A técnica de coleta utilizada foi a vácuo que compreende na punção da veia do paciente permitindo que o sangue flua diretamente para o tubo de coleta. Esta técnica é ideal, pois possibilita a coleta de vários tubos e se caracteriza por ser um sistema fechado e sem a necessidade de manuseio com a amostra.

Todo material foi coletado no laboratório do Hospital Israelita Albert Einstein, onde foram processados em até 24 horas pós-coleta e armazenados em biorrepositório.

Os procedimentos laboratoriais para obtenção das células mononucleares do sangue periférico (pBMC - Peripheral Blood Mononuclear Cell) foram realizados em cabine de segurança biológica. O protocolo de separação das células mononucleares está descrito em detalhes no anexo 1. Após processamento, as amostras foram armazenadas em freezer $-80^{\circ} \mathrm{C}$, assim como o soro coletado em um tubo adicional sem anticoagulante.

\subsection{Coleta e processamento de material: fezes}

Foram fornecidos 2 recipientes com tampa para a coleta das fezes. Os voluntários coletaram as amostras após esclarecimentos do processo de coleta pela equipe do Hospital Israelita Albert Einstein. Um recipiente foi encaminhado para o laboratório clínico para detecção de calprotectina fecal. O outro frasco foi encaminhado 
para o laboratório de pesquisa experimental do Instituto de Ensino e Pesquisa do Hospital Israelita Albert Einstein para a extração de material genético. As amostras foram mantidas em freezer $-80^{\circ} \mathrm{C}$ até a realização dos procedimentos.

\subsection{Tecido de mucosa e abscesso intestinal}

Amostras da mucosa intestinal e de abcessos de pacientes submetidos à colectomia prévia devido a progressão da DC foram obtidos de blocos parafinados e armazenados no centro de patologia clínica, após autorização do participante da pesquisa. A detecção de presença de micobactéria foi feita por coloração de Ziehl-Neelsen para pesquisa de bacilos álcool-ácido resistentes (BAAR) e através da técnica de extração de material genético utilizando o Kit Qiagen - Gene Read DNA FFPE ${ }^{\circledR}$.

\subsection{Cultura de Mycobacterium avium subsp. paratuberculosis}

Cepas inativadas de Mycobacterium avium subsp. paratuberculosis (CRNC-026) foram fornecidas pelo Laboratório Nacional Agropecuário LANAGRO/MG. O DNA foi extraído utilizando o Kit Invitrogen Purelink Genomic DNA ${ }^{\circledR}$.

\subsection{Dosagem de calprotectina}

A calprotectina é uma proteína ligadora de cálcio, produzida principalmente por granulócitos e sua concentração aumenta nas fezes como consequência da migração de neutrófilos, através da parede intestinal inflamada, para a luz do intestino. ${ }^{(70,71)}$ Para verificar a dosagem de calprotectina nas fezes dos pacientes, utilizamos o Kit Calprotectina Elisa Bühlmann, desenvolvido para extração e determinação quantitativa da calprotectina humana em amostras fecais. Foram necessários 50 a 100mg de amostra nativa de fezes para o procedimento de extração, coletadas em tubos lisos e armazenadas em $2-8^{\circ} \mathrm{C}$ por pelo menos 6 dias. Os extratos permanecem estáveis por pelo menos 7 dias nestas temperaturas.

Procedimento de extração: inserção de tubo previamente tarado 50 
a 100mg de amostra utilizando a alça de inoculação. Pesado novamente e acrescentado 49x o volume do peso de tampão de extração. A amostra foi homogeneizada em vortex com agitação vigorosa durante 30 minutos e transferido o homogeneizado para um tubo Eppendorf de $2 \mathrm{~mL}$ para centrifugação por 5 minutos a $3.000 \times \mathrm{g}$. O sobrenadante foi transferido para um novo tubo e realizou-se teste de Elisa conforme protocolo laboratorial já estabelecido.

\subsection{Hemograma, coagulograma e ensaios bioquímicos}

Para análises sanguíneas, $5 \mathrm{~mL}$ de sangue com anticoagulante ácido etilenodiamino tetra-acético (EDTA - Ethylenediamine tetraacetic acid), $5 \mathrm{~mL}$ de sangue sem soro e $5 \mathrm{~mL}$ com anticoagulante citrato de fosfato e dextrose (CPD - citratephosphate-dextrose) foram encaminhadas para avaliação do laboratório clínico do Hospital Israelita Albert Einstein.

\subsection{Extração de DNA de fezes}

Para extração de DNA das fezes de pacientes utilizamos o kit Invitrogen Purelink Genomic DNA ${ }^{\circledR}$, seguindo o protocolo e instruções fornecidas pelo fabricante. O DNA total foi dissolvido em 100mg de eluente específico do kit e armazenado à $-20^{\circ} \mathrm{C}$ até a realização do PCR. Todas as amostras foram quantificadas em equipamento Qubit e apenas amostras com concentração maior que $2 \mathrm{ng} / \mu \mathrm{L}$ foram utilizadas nos experimentos.

\subsection{PCR em tempo-real para detecção de Mycobacterium avium subsp. paratuberculosis (fezes e tecido)}

Reações de $25 \mu \mathrm{L}$ foram preparadas utilizando $3 \mu \mathrm{L}$ de DNA misturado a 1 $\mu \mathrm{M}$ de cada primer CN1(5'- CTGTGTTGGATGGCCGAAGG -3') e CN2(5'GCCACAACCACCTCCGTAAC -3') e ao Mix de RT- PCR (Power Syber Green Master Mix PCR utilizando o equipamento QuantStudio ${ }^{\mathrm{TM}}$ PCR em tempo-real Systems (Applied Biosystems ${ }^{\mathrm{TM}}$ ). A reação foi realizada com um ciclo inicial de $94^{\circ} \mathrm{C}$ por 5 
minutos seguidas de 30 ciclos de $94^{\circ} \mathrm{C}$ por 1 minuto e $56^{\circ} \mathrm{C}$ por 10 segundos.

\subsection{Cálculo do índice de atividade da doença}

A equação para calcular o índice de atividade da DC foi desenvolvida por um grupo de estudo da National Cooperative Crohn's Disease. Este índice utiliza oito variáveis selecionadas (Anexo 2). Os valores de índice menores e igual a 150 estão associados à doença em remissão, de 150 a 220 grau leve, 220 a 450 doença em estágio moderado e acima de 450 níveis graves de atividade da doença.

\subsection{Aspectos éticos}

Este trabalho foi desenvolvido com a aprovação ética CAAE: 38707914.0.0000.0071.

\subsection{Análise estatística}

Os dados foram descritos por meio de frequências absolutas e relativas para as variáveis categóricas e por medianas, quartis e valores mínimos e máximos para as variáveis quantitativas. As distribuições das variáveis numéricas foram estudadas por meio de gráficos histogramas e boxplots e pelo teste de normalidade de Shapiro-Wilk.

Para verificar diferenças entre os Grupos Controle e Grupo Pacientes foram utilizados testes de qui-quadrado ou testes exatos de Fisher para as variáveis categóricas e testes não paramétricos de Mann-Whitney para as variáveis quantitativas. As análises foram realizadas com o auxílio do pacote estatístico SPSS e o nível de significância fixado em $5 \%$. 


\section{RESULTADOS}

\subsection{Caracterização da população}

Foram analisados para este estudo 52 pacientes com diagnóstico comprovado de DC, por colonoscopia, imagens e testes laboratoriais e 43 controles sem doenças crônicas diagnosticadas. Amostras de sangue e fezes foram coletadas de todos os indivíduos que aceitaram fazer parte do estudo a partir da assinatura do TCLE. Dos 52 pacientes, 7 possuíam amostras de tecido retirado em decorrência de colectomia e consentiram sua doação para este estudo.

No Grupo Pacientes, observamos idades entre 19,2 anos e 66,6 anos, com mediana de 36,1 anos. No Grupo Controle observamos idades entre 19,0 e 76,0 anos, com mediana de 37,0 anos. A distribuição dos gêneros foi similar nos dois grupos e não há evidências de diferenças entre os grupos quanto à idade (Tabela 1).

Tabela 1. Comparação entre os grupos quanto a gênero e idade

\begin{tabular}{lccc}
\hline \multirow{2}{*}{ Variável } & \multicolumn{2}{c}{ Grupo } & \multirow{2}{*}{ Valor-p } \\
\cline { 2 - 3 } & $\begin{array}{c}\text { Pacientes } \\
(\mathbf{n}=\mathbf{5 2})\end{array}$ & $\begin{array}{c}\text { Controle } \\
(\mathbf{n}=\mathbf{4 3})\end{array}$ & $0,883^{*}$ \\
\hline Gênero n(\%) & $37(71,2)$ & $30(69,8)$ & \\
$\quad$ Mínimo & $15(28,8)$ & $13(30,2)$ & $0,540^{* *}$ \\
$\quad$ Masculino & & & \\
Idade (anos) & $36,1(28,2 ; 41,5)$ & $37,0(30,0 ; 44,0)$ & \\
$\quad$ Mediana (1-quartil; 3o quartil) & $19,2-66,6$ & $19,0-76,0$ & \\
$\quad$ Mínimo - Máximo & ${ }^{*}$ Teste de qui-quadrado. ${ }^{*}$ Teste não paramétrico de Mann-Whitney.
\end{tabular}

\section{2 Índice de atividade da doença e regime terapêutico}

Para avaliar o grau de atividade da doença no Grupo Pacientes, utilizou-se o índice de Atividade da Doença de Crohn (IADCI). Verificou-se uma heterogeneidade na população estudada onde havia pacientes em diferentes estágios de atividade (doença em remissão e doença ativa) (Tabela 2). 
Tabela 2. Grau de Atividade da doença de Crohn no grupo de pacientes

\begin{tabular}{lc}
\hline - IADC* & \\
\hline Mediana (1ํoquartil; 3 quartil) & $170,0(96,0 ; 262,0)$ \\
Mínimo - Máximo & $14,0-1088,0$ \\
$\leq 150$ doença em remissão & $23(45,1 \%)$ \\
de 150 a 220, doença leve & $9(17,6 \%)$ \\
de 220 a 450, doença moderada & $14(27,5 \%)$ \\
> 450 doença grave & $5(9,8 \%)$ \\
\hline Total & $51(100,0 \%)$ \\
\hline
\end{tabular}

*IACD: Índice de Atividade da Doença de Crohn.

Avaliamos a relação entre a classificação da doença por IADC e o tipo de tratamento, considerando categorias formadas por valores até 220 ou maiores (Tabela 3). Dentre os com tratamento biológico, 44\% estavam com a medida de IADC alterada e entre os com outros tratamentos a proporção foi 38,1\%. Todos os indivíduos sem tratamentos possuíam valores de IADC até 220. Não houve evidências de associação entre IADC e o tipo de tratamento (valor-p 0,231).

Tabela 3. Relação entre tipo de tratamento e Índice de Atividade da Doença

\begin{tabular}{|c|c|c|c|c|}
\hline \multirow[b]{2}{*}{ Tipo de tratamento } & \multicolumn{2}{|c|}{ IADC } & \multirow{2}{*}{$\begin{array}{l}\text { Total } \\
\mathrm{n}(\%)\end{array}$} & \multirow{2}{*}{$\begin{array}{c}\text { Valor-p } \\
\text { (Teste de Fisher) }\end{array}$} \\
\hline & $\begin{array}{c}\text { Até } 220 \\
\mathrm{n}(\%)\end{array}$ & $\begin{array}{l}>220 \\
\mathrm{n}(\%)\end{array}$ & & \\
\hline & & & & 0,231 \\
\hline Biológico & $14(56,0)$ & $11(44,0)$ & $25(100,0)$ & \\
\hline Outros & $13(61,9)$ & $8(38,1)$ & $21(100,0)$ & \\
\hline Sem tratamento & $5(100,0)$ & $0(0,0)$ & $5(100,0)$ & \\
\hline Total & $32(62,7)$ & $19(37,3)$ & $51(100,0)$ & \\
\hline
\end{tabular}

Dos 52 indivíduos com DC, 11,5\% estava sem tratamento e 88,5\% estavam com regime terapêutico estabelecido. $O$ tratamento mais utilizado foi 0 biológico $(48,1 \%)$ sendo que $48,1 \%$ faziam associação com uso de azatioprina. $O$ tempo de tratamento variou entre seis meses e 25 anos, sendo que $39,5 \%$ estavam em tratamento há mais de 10 anos (Tabela 4). 
Tabela 4. Características do tratamento

\begin{tabular}{lc}
\hline Variável & $\begin{array}{c}\text { Pacientes } \\
(\mathbf{n}=52)\end{array}$ \\
\hline Uso de Azatioprina n(\%) & \\
Não & $27(51,9)$ \\
Sim & $25(48,1)$ \\
Tipo de tratamento n(\%) & $22(42,3)$ \\
Biológico & $3(5,8)$ \\
Biológico e imunossupressor & $6(11,5)$ \\
Corticoide & $9(17,3)$ \\
Imunossupressor & $3(5,7)$ \\
Mezalazina & $3(5,8)$ \\
Mezalazina e Corticoide & $2(3,8)$ \\
Sem tratamento atual & $1(1,9)$ \\
Sem tratamento há três anos & $3(5,8)$ \\
Virgem de Tratamento & \\
Tempo de tratamento em anos & $8,0(2,0 ; 16,0)$ \\
Mediana (1ำquartil; 3ํquartil) & $0,5-25,0$ \\
Mínimo - Máximo & $7(16,3)$ \\
1 ano ou menos & $13(30,2)$ \\
Mais de 1 a cinco anos & $6(14,0)$ \\
Mais de cinco a 10 anos & $17(39,5)$ \\
\hline
\end{tabular}

\subsection{Dados laboratoriais}

Avaliamos as diferenças entre os grupos quanto às medidas laboratoriais e observamos evidências de maiores valores de Calprotectina entre os indivíduos com DC (valor- $p<0,001)$. Para as demais medidas não observamos evidências de diferenças entre casos e controles (Tabela 5).

Tabela 5. Dados de testes laboratoriais

\begin{tabular}{|c|c|c|c|}
\hline \multirow[b]{2}{*}{ Teste } & \multicolumn{2}{|c|}{ Grupos } & \multirow[b]{2}{*}{ Valor-p } \\
\hline & $\begin{array}{c}\text { Pacientes } \\
(n=52)\end{array}$ & $\begin{array}{c}\text { Controle } \\
(n=43)\end{array}$ & \\
\hline Hemoglobina (\%) & & & $0,887^{*}$ \\
\hline Mediana ( $1^{\circ}$ quartil; $3^{\circ}$ quartil) & $13,4(12,9 ; 14,7)$ & $13,2(12,4 ; 14,1)$ & \\
\hline Mínimo - Máximo & $10,4-16,2$ & $10,3-16,0$ & \\
\hline Hematócrito (\%) & & & $0,390^{*}$ \\
\hline Mediana ( $1^{\circ}$ quartil; $3^{\circ}$ quartil) & $39,2(36,8 ; 41,5)$ & $39,2(37,2 ; 42,9)$ & \\
\hline Mínimo - Máximo & $32,0-45,9$ & $32,8-49,9$ & \\
\hline Leucócitos (x10^3/uL) & & & $0,300^{*}$ \\
\hline Mediana ( $1^{\circ}$ quartil; $3^{\circ}$ quartil) & $7,2(6,0 ; 8,3)$ & $7,0(5,5 ; 8,2)$ & \\
\hline Mínimo - Máximo & $4,3-18,0$ & $4,2-13,2$ & \\
\hline
\end{tabular}


...continuação

\begin{tabular}{|c|c|c|c|}
\hline Neutrófilos (\%) & & & $0,187^{*}$ \\
\hline Mediana (1ำquartil; 3ำ quartil) & $61,8(56,8 ; 66,6)$ & $61,2(52,9 ; 64,6)$ & \\
\hline Mínimo - Máximo & $42,3-87,0$ & $43,8-73,7$ & \\
\hline Eosinófilos (\%) & & & $0,302^{*}$ \\
\hline Mediana (1ำquartil; 3ำ quartil) & $2,0(1,0 ; 2,9)$ & $1,4(0,9 ; 2,5)$ & \\
\hline Mínimo - Máximo & $0,0-6,8$ & $0,4-8,0$ & \\
\hline Basófilos (\%) & & & $0,171^{*}$ \\
\hline Mediana (1ำquartil; 3ำ quartil) & $0,3(0,2 ; 0,5)$ & $0,4(0,3 ; 0,5)$ & \\
\hline Mínimo - Máximo & $0,1-2,1$ & $0,1-1,6$ & \\
\hline Linfócitos (\%) & & & $0,079^{*}$ \\
\hline Mediana (1ํquartil; $3^{\circ}$ quartil) & $27,7(22,8 ; 32,5)$ & $30,4(26,5 ; 35,8)$ & \\
\hline Mínimo - Máximo & $6,0-43,6$ & $17,0-45,5$ & \\
\hline Monócitos (\%) & & & $0,817^{*}$ \\
\hline Mediana (1ํquartil; $3^{\circ}$ quartil) & $7,7(6,3 ; 9,1)$ & $7,7(6,4 ; 8,8)$ & \\
\hline Mínimo - Máximo & $3,0-16,4$ & $4,8-14,8$ & \\
\hline Ferro sérico (mcg/dL) & & & $0,374^{*}$ \\
\hline Mediana (1ำquartil; $3^{\circ}$ quartil) & $85,0(58,0 ; 111,0)$ & $93,0(67,0 ; 115,0)$ & \\
\hline Mínimo - Máximo & $15,0-199,0$ & $24,0-172,0$ & \\
\hline Vitamina B12 (pg/mL) & & & $0,463^{*}$ \\
\hline Mediana (1ํquartil; 3o quartil) & $331,0(263,0 ; 456,0)$ & $348,5(240,0 ; 417,0)$ & \\
\hline Mínimo - Máximo & $159,0-1000,0$ & $159,0-637,0$ & \\
\hline Proteína C-reativa (mg/dL) & & & $0,297^{*}$ \\
\hline Mediana (1ํquartil; 3ำ quartil) & $0,22(0,10 ; 0,78)$ & $0,16(0,07 ; 0,52)$ & \\
\hline Mínimo - Máximo & $0,0-7,3$ & $0,0-1,9$ & \\
\hline Bilirrubina total (mg/dL) & & & $0,826^{*}$ \\
\hline Mediana (1ํquartil; 3ำ quartil) & $0,60(0,40 ; 0,70)$ & $0,50(0,50 ; 0,70)$ & \\
\hline Mínimo - Máximo & $0,2-1,5$ & $0,3-1,1$ & \\
\hline Linfócitos totais $\left(\mathrm{mm}^{3}\right)$ & & & $0,861^{*}$ \\
\hline Mediana (1ํquartil; $3^{\circ}$ quartil) & $2024(1342 ; 2515)$ & $2058(1632 ; 2411)$ & \\
\hline Mínimo - Máximo & $510-3480$ & $1032-3485$ & \\
\hline Linfócitos CD3 $\left(\mathrm{mm}^{3}\right)$ & & & $0,843^{*}$ \\
\hline Mediana (1ํoquartil; 3ำ quartil) & $1588(1071 ; 1993)$ & $1489(1270 ; 1825)$ & \\
\hline Mínimo - Máximo & $392-2721$ & $638-2666$ & \\
\hline Linfócitos CD4 (mm³) & & & $0,689^{*}$ \\
\hline Mediana (1ํoquartil; 3ำ quartil) & $924(676 ; 1177)$ & $896(719 ; 1177)$ & \\
\hline Mínimo - Máximo & $141-2065$ & $400-2105$ & \\
\hline Linfócitos CD8 $\left(\mathrm{mm}^{3}\right)$ & & & $0,799^{*}$ \\
\hline Mediana (1ํoquartil; 3ำ quartil) & $452(341 ; 663)$ & $468(337 ; 583)$ & \\
\hline Mínimo - Máximo & $70-1465$ & $2-885$ & \\
\hline Relação CD4/CD8 & & & $0,176^{*}$ \\
\hline Mediana ( $1^{\circ}$ quartil; $3^{\circ}$ quartil) & $1,9(1,4 ; 2,5)$ & $2,1(1,5 ; 2,6)$ & \\
\hline Mínimo - Máximo & $0,8-9,1$ & $1,0-70,6$ & \\
\hline Calprotectina (ug/g)\$ & & & $<0,001^{*}$ \\
\hline Mediana (1ํquartil; $3^{\circ}$ quartil) & $422,0(110,8 ; 1019,0)$ & $75,7(47,0 ; 209,0)$ & \\
\hline Mínimo - Máximo & $14,1-1800,0$ & $30,0-1340,0$ & \\
\hline Calprotectina & & & $0,001 \#$ \\
\hline Valores normais $(<50 \mathrm{microg} / \mathrm{g})$ & $3(5,8 \%)$ & $12(27,9 \%)$ & \\
\hline
\end{tabular}




\begin{tabular}{lcc} 
Indeterminado (50 a 200 microg/g) & $17(32,7 \%)$ & $19(44,2 \%)$ \\
Elevados (>200 microg/g) & $32(61,5 \%)$ & $12(27,9 \%)$ \\
\hline Valores acima do limite de detecção de & 1800 foram considerados como 1800. \#: Teste de qui-
\end{tabular}

\subsection{Tecido de mucosa e abscesso intestinal}

Lâminas de tecido de 5 pacientes foram avaliadas pela técnica de Ziehl-Neelsen para pesquisa de BAAR. Não foi possível identificar presença de micobacterias nas lâminas analisadas por meio da técnica utilizada (dados obtidos do serviço de patologia onde as amostras estavam armazenadas).

\subsection{Padronização do protocolo de PCR em tempo-real}

Para realização dos procedimentos de Real-Time PCR, sintetizamos uma sequência alvo conservado do DNA de Mycobacterium avium subsp. paratuberculosis em um plasmídio de Escherichia coli, contendo 3144bp. A região da MAP de interesse continha 770bp (Figura 3). O DNA plasmídico foi purificado de bactérias transformadas e concentração determinada por UV espectroscopia. A construção final foi verificada por sequenciamento. A sequência $A$ congruência da sequência dentro dos sites de inserção foi de $100 \%$. O liofilizado foi diluído em $50 u L$ de água DNAse free e utilizada na padronização das reações de RT_PCR.

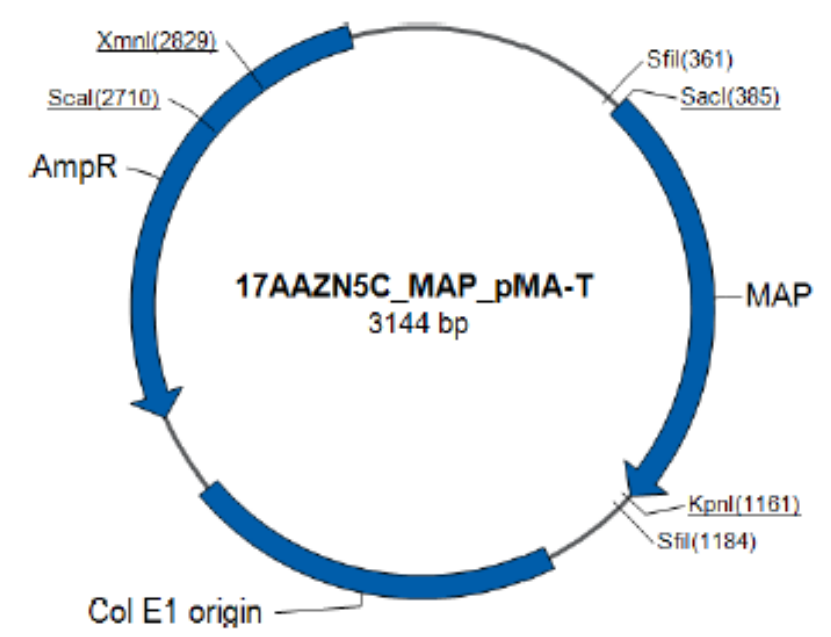

Figura 3. Fragmento de Mycobacterium avium subsp. paratuberculosis sintética inserida em pMA-T 
Os primers foram desenhados utilizando o programa Primer Select e testados utilizando o equipamento Applied Biosystems QuantStudio ${ }^{\mathrm{TM}}{ }^{\circledR}$. Para avaliar a capacitação de amplificação na sequencia alvo, fizemos diluições do plasmídio de interesse conforme tabela 6 .

Tabela 6. Diferentes concentrações do plasmídio e o número de cópias contido em cada concentração

\begin{tabular}{lc}
\hline $\begin{array}{l}\text { Concentração } \\
(\mathbf{n g} / \mu \mathrm{L})\end{array}$ & Número de cópias \\
\hline 1.87 & $5.51 \times 10^{8}$ \\
0.298 & $8.78 \times 10^{7}$ \\
0.0298 & $8.78 \times 10^{6}$ \\
0.00298 & $8.78 \times 10^{5}$ \\
0.000298 & $8.78 \times 10^{4}$ \\
0.0000298 & $8.78 \times 10^{3}$ \\
0.00000298 & 878 \\
0.00000298 & 87.8 \\
\hline
\end{tabular}

A sensibilidade do ensaio foi avaliada usando diferentes concentrações de plasmídio. O limite experimental reprodutível foi de 87.8 cópias, conforme detectado por 35 ciclos de PCR (Figura 4). Para verificação de anelamento inespecíficos e dímeros utilizamos a curva de melting (Figura 5).

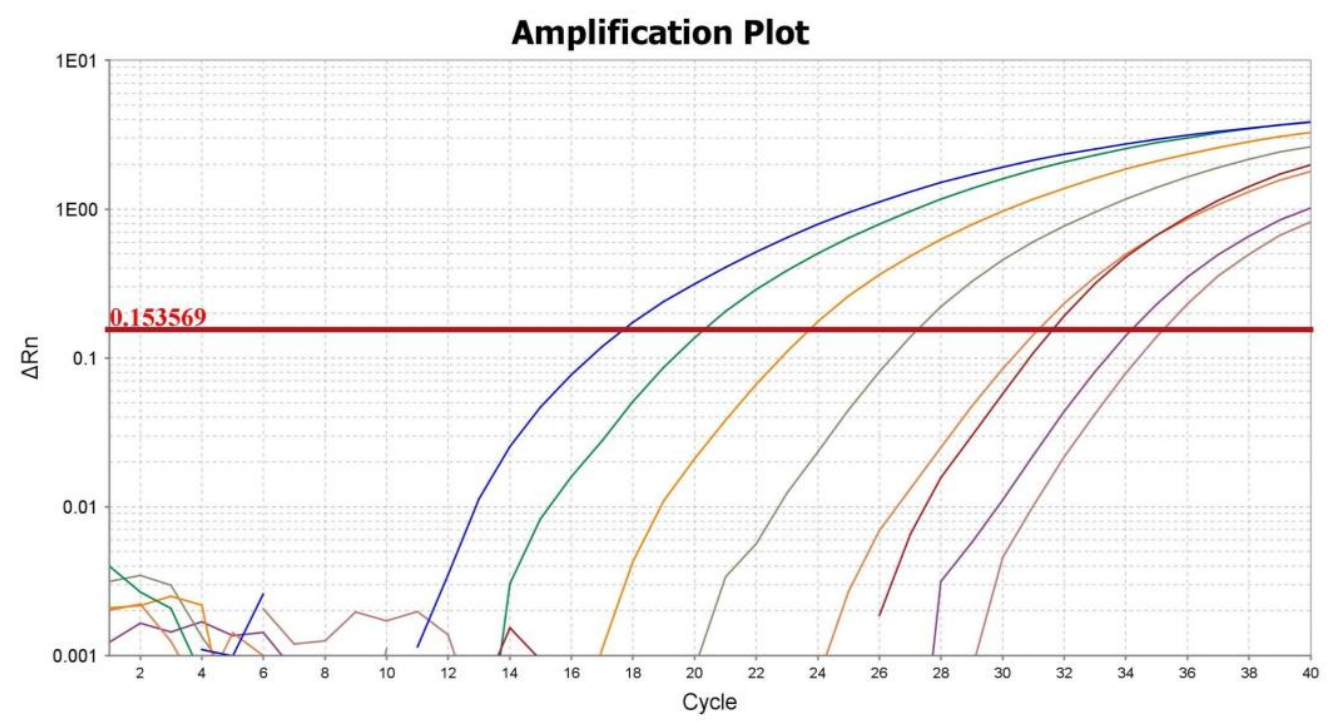

Figura 4. Sensibilidade do teste de PCR em tempo real nas diferentes concentrações do plasmídio 


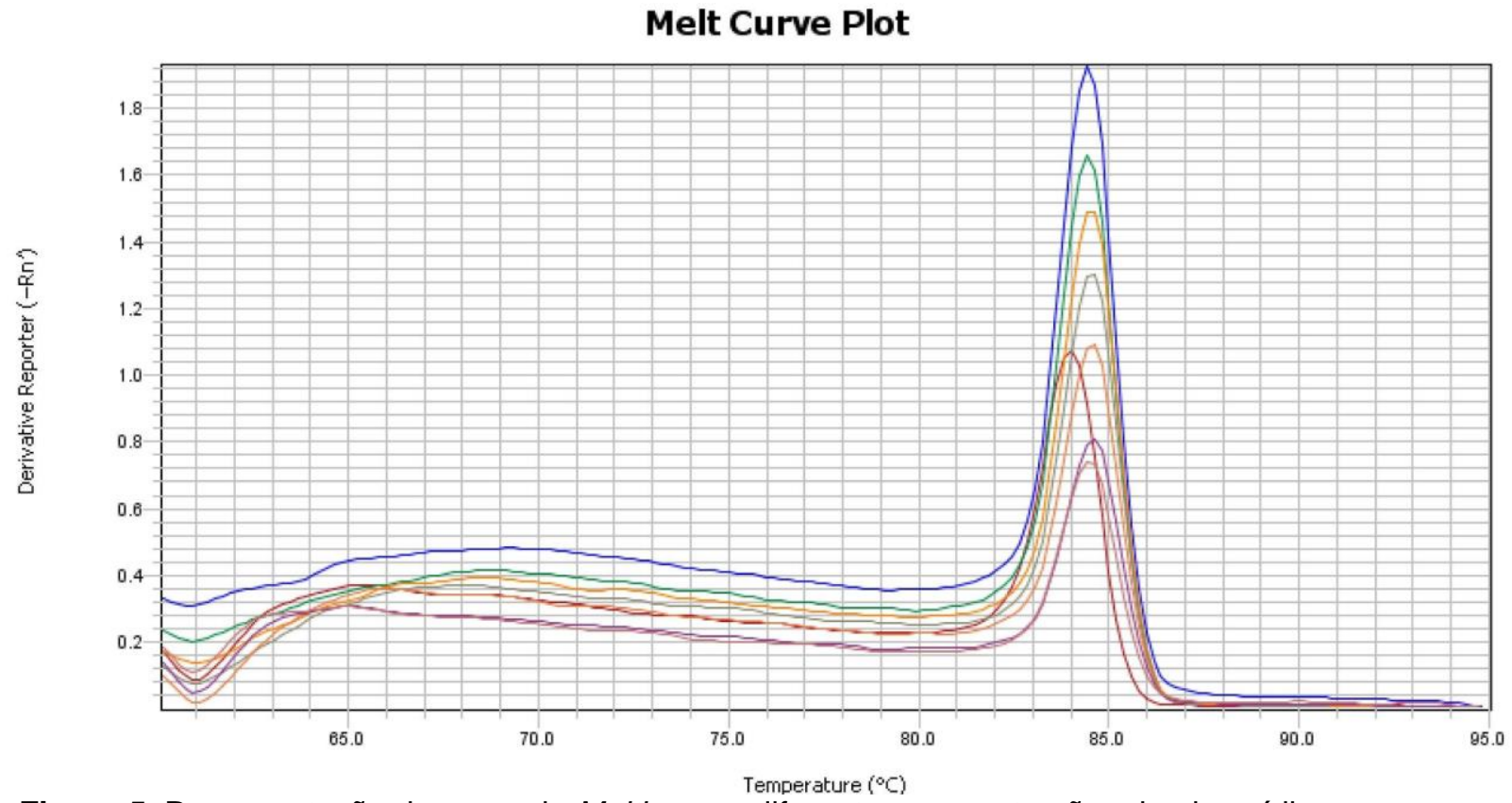

Figura 5. Representação da curva de Melting nas diferentes concentrações de plasmídio

\subsection{PCR em tempo-real}

Conforme observado nos gráficos abaixo, não detectamos presença de MAP em fezes de pacientes (Figura 6) e controles (Figura 7) e também não detectamos nos tecidos dos pacientes analisados (Figura 8). Em todos os experimentos, apenas o controle positivo foi amplificado.

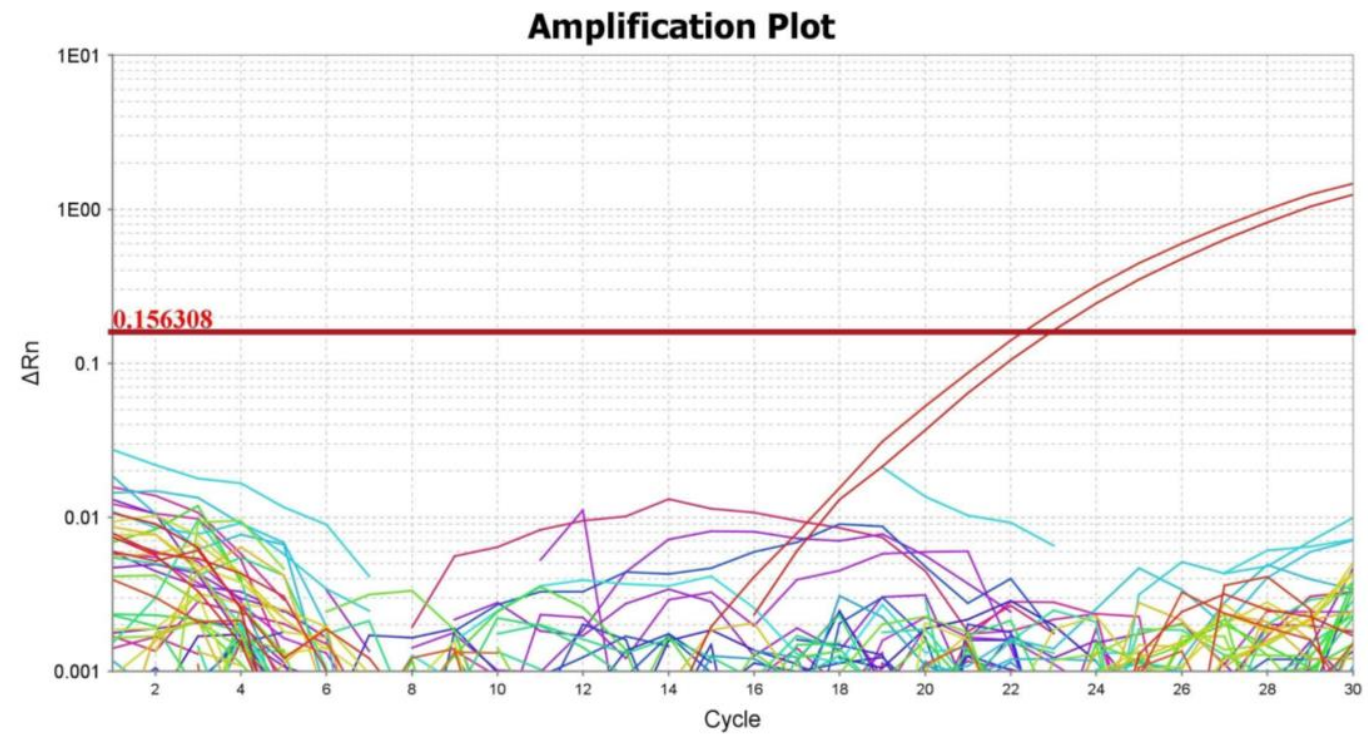

Figura 6. Resultado da amplificação de DNA extraído de fezes de pacientes portadores de doença de Crohn 


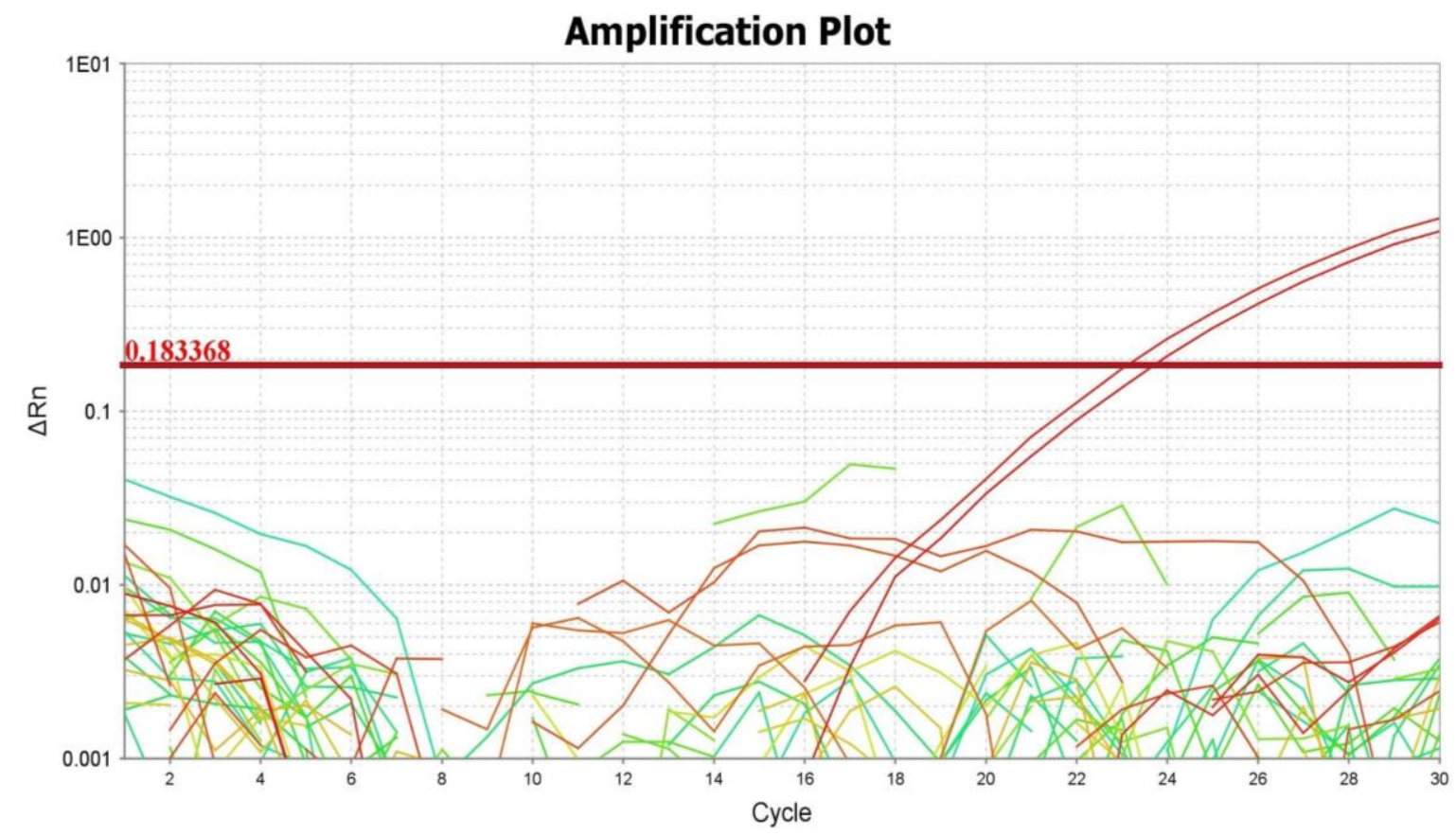

Figura 7. Resultado da amplificação de DNA extraído de fezes de voluntários sem doença (controles)

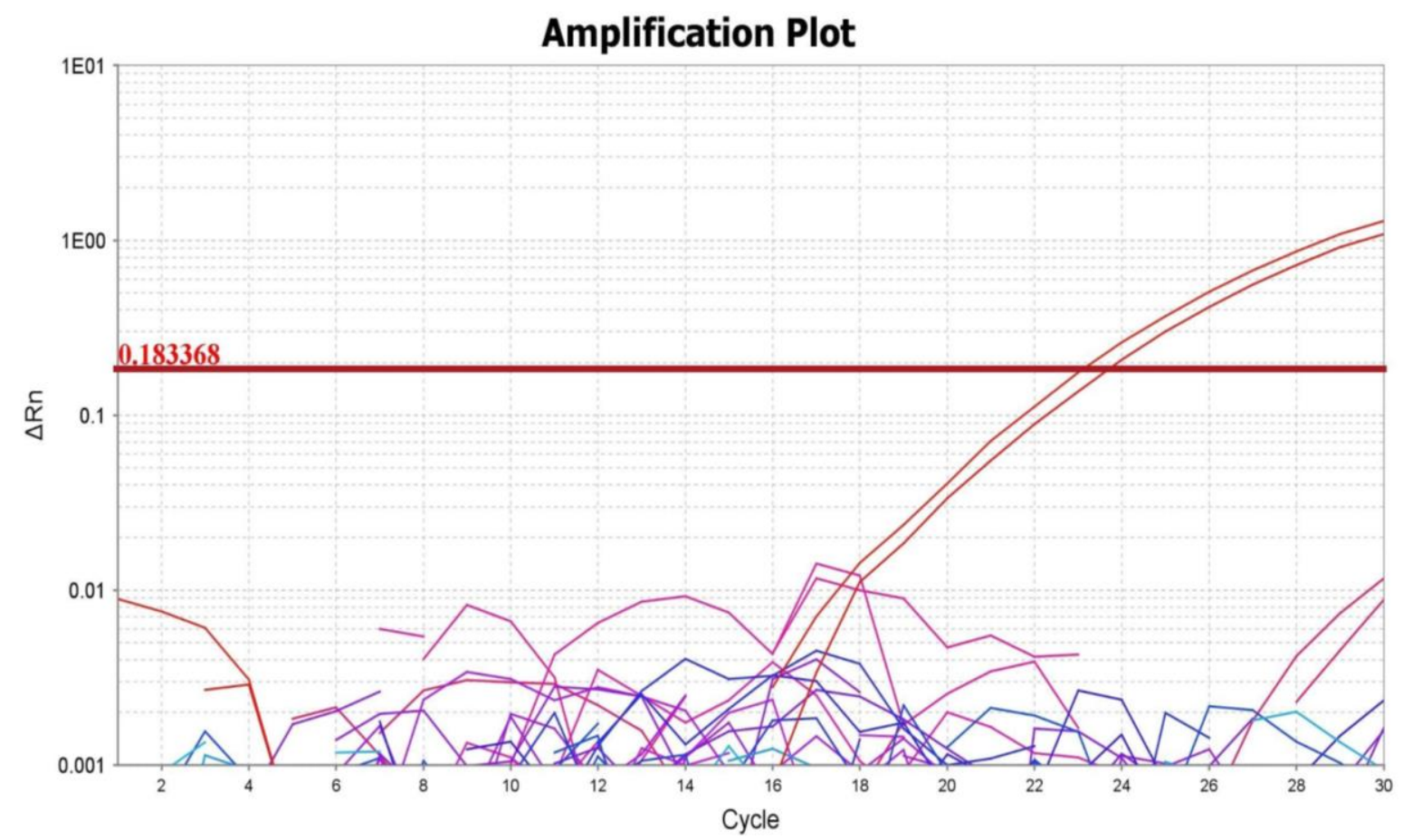

Figura 8. Resultado da amplificação de DNA extraído de tecido retirado de colectomia prévia de pacientes com DC 


\section{DISCUSSÃO}

O número de adultos jovens com diagnóstico de $\mathrm{DC}$ tem crescido exponencialmente. Últimos levantamentos, mostram que na América do Norte há uma incidência anual de 19,2 por 100.000 indivíduos-ano e uma prevalência em torno de 505 por 100.000 pessoas. $^{(72)}$ Nossa amostragem é predominantemente jovem, homogênea entres os grupos no que se refere a gênero e idade e representa grupos de diferentes níveis de atividade da doença.

Os exames laboratoriais podem ser úteis no manejo da doença e evitar testes invasivos desnecessários. Dentre os exames mais solicitados a dosagem de PCR tem sido considerada um teste importante na fase aguda da inflamação, apesar de ainda não estar claro seu valor como marcador clínico. ${ }^{(73)}$ Diferente dos achados de Henriksen et al., ${ }^{(72)}$ nossos pacientes não tiverem concentrações elevadas de PCR, mesmo nos casos em que o IADC estava elevado. Isso demonstra sua fraca sensibilidade, e um teste negativo não exclui a presença de inflamação ativa. ${ }^{(74)}$

Em conjunto com a PCR, a dosagem de calprotectina fecal tem sido utilizada como teste de auxílio clínico e seus valores podem permitir a diferenciação diagnóstica dentre os diferentes distúrbios intestinais. ${ }^{(75)}$ Nossos pacientes apresentaram níveis elevados deste marcador, mostrando similaridades com um estudo que analisou recentemente pacientes brasileiros com diferentes diagnósticos dentre as DII. ${ }^{(76)}$

Apesar dos avanços nas terapias biológicas e do diagnóstico precoce que tem permitido o manejo da doença, ainda não se encontrou respostas concretas que justifiquem o desbalanço imunológico. Alguns pesquisadores acreditam que a alteração da permeabilidade intestinal durante as fases ativas da DC poderiam explicar a inflamação crônica, devido à translocação de bactérias e outros antígenos através da mucosa, que são capazes de ativar o sistema imune inato da mucosa. ${ }^{(77)}$

$\mathrm{Na}$ tentativa de se encontrar os possíveis fatores ambientes que possam estar relacionados com o processo inflamatório intestinal, muitos pesquisadores têm focado seus esforços na busca de uma possível causa infecciosa para a doença. ${ }^{(18-20)}$

Em virtude das similaridades histológicas e clínicas da DC com a doença de Johne's, a MAP, organismo causador desta paratuberculose bovina, tem sido o maior alvo de investigação atual. Apesar da paratuberculose não ser 
considerada comum no Brasil, um grupo brasileiro identificou recentemente, material genômico de MAP em amostras de leite no nordeste. ${ }^{(78)}$ Uma vez que animais infectados são considerados uma possível fonte de transmissão para humanos, consideramos importante esta investigação em nossa população.

Em estudos diagnósticos, o teste de sensibilidade das reações de detecção é um passo importante e que permite a confiabilidade dos dados. Estudos similares, utilizando técnicas de PCR em tempo real, mostraram sensibilidade de detecção de 5 cópias de MAP detectadas em 40 ciclos de PCR. ${ }^{(49)}$ Em nossa padronização, tivemos um limite de detecção de 87,8 cópias em 35 ciclos.

A avaliação de MAP em fezes tem sido uma alternativa mais viável para pesquisa de $\operatorname{MAP}^{(33)}$ uma vez que seu acesso é menos invasivo que a biópsia intestinal. Apesar disso, em nosso estudo não detectamos cepas de MAP em fezes de pacientes e voluntários saudáveis.

Um estudo recente mostrou uma alta prevalência de MAP em pacientes com diagnóstico de DC, a partir da extração de DNA de tecido fresco retirado por colonoscopia. ${ }^{(34)} \mathrm{Na}$ tentativa de reproduzir estudos semelhantes, que foram capazes de identificar a presença deste microrganismo em pacientes com DC de diferentes etnias, ${ }^{(34-36)}$ nosso grupo extraiu DNA de tecido ileocecal proveniente de cirurgias prévias e que estavam armazenados no laboratório de patologia de nossa instituição. Não detectamos a presença de MAP nos tecidos analisados. O tempo longo e a forma de armazenamento dos tecidos utilizados podem ter impactado em uma possível detecção desta cepa nas amostras de nossos pacientes. Além disso, na ocasião do procedimento cirúrgico, todas as amostras haviam sido testadas através da técnica Ziehl-Neelsen para pesquisa de BAAR, e todos tiverem detecção negativa de micobacterias (dados não mostrados). Pesquisadores já levantaram uma hipótese de que este tipo específico de micobactéria não é sensível para este teste, uma vez que culturas de sangue periférico positivas para MAP não apresentaram achados positivos nas colorações de BAAR nas primeiras semanas de incubação. ${ }^{(79)}$

Apesar de não termos detectado a presença de MAP em fezes e tecidos dos nossos pacientes, não foi possível descartar um possível papel etiológico deste patógeno na DC, uma vez que todos os pacientes recrutados tiverem ou estavam sob regime terapêutico para controle da doença, o que inclui uso de antibioticoterapia. Além disso, a azatioprina já mostrou ter um efeito deletério de MAP in vitro ${ }^{(80)}$ e quase $50 \%$ dos nossos pacientes estavam em uso deste agente. 


\section{CONCLUSÕES}

1. Foi estruturado um protocolo de padronização experimental para extração e detecção de Mycobacterium avium subsp. paratuberculosis, mesmo trabalhando com uma cepa que possui características celulares que dificultam seu crescimento, manutenção e extração de material genético;

2. Em virtude das características da cepa estudada, sua possível detecção também requer critérios específicos, como o uso de amostras de tecido frescos retiradas diretamente das lesões intestinais e recrutamento de pacientes com critérios de inclusão específicos que excluam pacientes em tratamento para a doença e que tenham feito uso de antibiótico nos últimos meses;

3. Com o avanço das terapias biológicas, o manejo da doença tem sido alcançado e a manutenção da remissão atingida em grande parte dos pacientes, evitando procedimentos cirúrgicos resultantes de complicações da doença. Este fator em si é um limitante para estudos de análise de microorganismos com aderência á mucosa intestinal, como é o caso da micobactéria estudada;

4. É necessário avaliar a forma como os estudos que visam correlacionar a presença de Mycobacterium avium subsp. paratuberculosis com Doença de Crohn, sejam conduzidos, uma vez que mesmo se achando uma correlação positiva, existe a dificuldade de introduzir a detectação da presença da cepa na prática clínica e diagnóstica. 
Anexo 1. Protocolo para obtenção de células mononucleares (PBMC)

\section{MATERIAIS:}

- Tubo Falcon de 50mL

- Garrafa de cultura

- Caneta permanente

- Papel toalha

- Gaze

- Álcool (70\%)

- Estante para tubos

- Pipetador automático

- Pipetas de $20 \mu \mathrm{L}, 200 \mu \mathrm{L}$ e $1.000 \mu \mathrm{L}$

- Ponteiras de $200 \mu \mathrm{L}$ e $1.000 \mu \mathrm{L}$

- Ponteiras de sorológica de $5 \mathrm{~mL}, 10 \mathrm{~mL}$ e de $25 \mathrm{~mL}$

- Etiqueta para identificar os criotubos

- Recipiente para descarte contendo hipoclorito $2 \%$

- Descarte de material biológico (Descarpack)

- HANKS

- Ficoll

- Lisante ACK

- Meio de cultura R10

- Azul de Tripan $(0,1 \%)$

- Lâmina do contador de células Counter Cell

- Calculadora

- Papel sulfite

- Caneta esferográfica

- Eppendorf

EQUIPAMENTOS:

- Cabine de segurança biológica (Fluxo Laminar)

- Centrífuga

- Microscópio óptico

\section{SIGLAS:}

- U.V. - Luz ultravioleta

- ${ }^{\circ} \mathrm{C}$ - Graus Celsius

- $\mathrm{mL}$ - unidade de volume mililitro

- $\mathrm{cm}$ - unidade de medida centímetro 


\section{PROCEDIMENTO:}

1. Após a esterilização do fluxo laminar ( 15 minutos na UV), coloque dentro do mesmo todo material que será utilizado no experimento;

2. Identifique a garrafa de cultura com o número e as iniciais do doador;

3. Transfira todas as amostras de sangue periférico fresco dos tubos de EDTA para a garrafa de cultura vertendo os tubos delicadamente;

4. Acrescente a mesma proporção de HANKS na garrafa de cultura;

5. Homogeneize suavemente o conteúdo da garrafa de cultura por processo de inversão, de cinco a oito vezes delicadamente, obtendo-se assim o concentrado de células diluído;

6. Busque o Ficoll na geladeira;

7. Pegue 3 tubos Falcon e com o auxílio de uma pipeta sorológica de $25 \mathrm{~mL}$ acrescente $15 \mathrm{~mL}$, em cada um dos tubos, de Ficoll gelado;

a. Exemplo: no caso de obter $100 \mathrm{~mL}$ de concentrado de células diluído, dividir em proporções iguais (100 dividido por $3=33 \mathrm{~mL}$ de concentrado diluído);

2. Incline o tubo Falcon com Ficoll a $45^{\circ} \mathrm{C}$ e transfira com o auxílio de uma pipeta sorológica de $25 \mathrm{~mL}, 33 \mathrm{~mL}$ de concentrado de células diluído pela parede do tubo de maneira delicada e devagar para que a amostra permaneça em cima do Ficoll e não o perfure;

3. Tampe os 3 tubos de Falcon e leve para centrifugar durante 40 minutos a $\mathbf{2 . 3 0 0}$ rpm a temperatura de $18-20^{\circ} \mathrm{C}$, com aceleração de 4 e break de 0 ;

4. Ao término da centrifugação verifique a formação da nuvem de células mononucleares;

5. Com o auxílio de uma pipeta sorológica de $10 \mathrm{~mL}$ (ou pipeta Pasteur), retire todo o sobrenadante e despreze no recipiente contendo hipoclorito a $2 \%$, deixe cerca de $1 \mathrm{~cm}$ de sobrenadante acima da nuvem;

6. Em um novo tubo Falcon colete a nuvem de células mononucleares completamente com o auxílio de uma pipeta sorológica ou pipeta Pasteur (cuidado para não pegar Ficoll);

7. Neste tubo que contém a nuvem de células mononucleares, acrescente o volume de HANKS até atingir a marca de $50 \mathrm{~mL}$ do tubo;

8. Centrifugue durante 10 minutos, a 1.700rpm;

9. Verifique a presença da formação do pellet; 
10.Despreze o sobrenadante no recipiente com hipoclorito a $2 \%$;

11. Tampe o tudo Falcon e homogeneize o pellet cuidadosamente até que ele se solte completamente do fundo do tudo;

12. Complete o volume até $50 \mathrm{~mL}$ com HANKS;

13. Centrifugue durante 10 minutos, a 1.700rpm;

14. Verifique a formação do pellet;

15. Despreze o sobrenadante no recipiente com hipoclorito a $2 \%$;

16. Tampe o tudo Falcon e homogeneize o pellet cuidadosamente até que ele se solte completamente do fundo do tudo;

17. Com o auxílio de uma pipeta sorológica de $5 \mathrm{~mL}$, acrescente $3 \mathrm{~mL}$ de lisante - ACK e aguarde 2 minutos;

18. Para neutralizar a ação do ACK acrescente $10 \mathrm{~mL}$ de meio de cultura R10;

19. Centrifugue durante 10 minutos, a 1.700rpm;

20. Verifique a formação do pellet;

21. Despreze o sobrenadante no recipiente com hipoclorito a $2 \%$;

22. Tampe o tudo Falcon e homogeneize o pellet cuidadosamente até que ele se solte completamente do fundo do tubo;

23. Acrescente $10 \mathrm{~mL}$ de meio de cultura R10;

24. Homogeneize delicadamente (ñão por inversão para que não fiquem células na tampa do tubo);

25. Em um tubo Eppendorf, com o auxílio de uma pipeta de $20 \mu \mathrm{L}$ acrescente $10 \mu \mathrm{L}$ de Azul de Tripan (0,1\%), já previamente identificado;

26. A partir do concentrado de células diluído, retire uma alíquota de $10 \mu \mathrm{L}$ com o auxílio de uma pipeta de $20 \mu \mathrm{L}$ e após enxugar a ponteira, transfira a alíquota para o Eppendorf homogeneizando cuidadosamente para que a diluição fique balanceada;

27. Retire $10 \mu \mathrm{L}$ da amostra da suspensão celular com o auxílio de uma pipeta de $20 \mu \mathrm{L}$ e transfira seu conteúdo para uma lâmina do contador de células;

28. Efetue a contagem de células mononucleares viáveis;

29. Realize os cálculos: Número de células viáveis (live) x valor da diluição do Azul de Tripan $x$ volume resuspendido em meio de cultivo $\mathrm{R} 10$. O resultado totalizará o número de células que possui no volume de suspensão celular;

30.Defina e acerte a concentração celular que deverá ser utilizada no experimento. A concentração de células padrão para PBMC é de $1 \times 10^{7}$ células por $1 \mathrm{~mL}$ de meio de congelamento. 


\section{Observações Importantes}

- Não pipetar meio R10 diretamente de seu recipiente, pois este contamina facilmente

- Colocar as células para congelar no "Strata Cooler" gelado

- Colocar o meio de congelamento gelado no pellet de células

- Ressuspender o pellet logo após a centrifugação pois o achatamento mata as células.

- Se for preciso fazer uma pausa no procedimento, procurar deixar as células sempre no meio R10

- Para o PBMC sempre usar R10 suplementado, e nunca R10 com DNAse. 
Anexo 2. Índice de Atividade da Doença de Crohn (IADC)

\begin{tabular}{|c|c|}
\hline \multicolumn{2}{|c|}{ Indice de Atividade da Doença de Crohn - IADC } \\
\hline & Multiplicado por \\
\hline Número de evacuações líquidas na última semana & 2 \\
\hline \multicolumn{2}{|l|}{ Dor abdominal (nos últimos 7 dias) } \\
\hline Nenhuma $=0$ & 5 \\
\hline Moderada $=2$ & \\
\hline \multicolumn{2}{|l|}{ Estado geral (nos últimos 7 dias) } \\
\hline Otimo $=0 \quad$ Bom $=1$ & 7 \\
\hline Péssimo $=4$ & \\
\hline \multicolumn{2}{|l|}{ Número de complicações (nos últimos 7 dias) } \\
\hline \multirow{6}{*}{\multicolumn{2}{|c|}{$\begin{array}{l}\text { Artralgia/artrite } \\
\text { Irite/uveíte } \\
\text { Eritema nodoso/pioderma gangrenoso/aftas orais } \\
\text { Fissura anal, fístula ou abscesso anal } \\
\text { Outras fístulas } \\
\text { Febre } 37,8^{\circ} \mathrm{C}\end{array}$}} \\
\hline & \\
\hline & \\
\hline & \\
\hline & \\
\hline & \\
\hline \multirow{3}{*}{\multicolumn{2}{|c|}{$\begin{array}{l}\text { Consumo de antidiarreico } \\
\text { Não }=0 \\
\text { Sim }=1\end{array}$}} \\
\hline & \\
\hline & \\
\hline \\
\hline Ausente $=0$ & 10 \\
\hline Duvidosa = 2 & \\
\hline Bem definida $=5$ & \\
\hline \multirow{2}{*}{\multicolumn{2}{|c|}{$\begin{array}{l}\text { Déficit do hematócrito: } \\
\text { Homem: } 47-\mathrm{Ht} \%\end{array}$}} \\
\hline & 6 \\
\hline \multicolumn{2}{|l|}{ Mulher: $42-\mathrm{Ht} \%$} \\
\hline Peso: $1-$ Peso $\quad \times 100$ & \\
\hline Peso padrão & 1 \\
\hline (Adicione ou subtraia segundo o & \\
\hline
\end{tabular}

Fonte: Traduzido e adaptado de Best WR, Becktel JM, Singleton JW, Kern F Jr. Development of a Crohn's disease activity index. National Cooperative Crohn's Disease Study. Gastroenterology. 1976;70(3):439-44. (81) $^{-1}$ 


\section{REFERÊNCIAS}

1. Kaser A, Blumberg RS. Endoplasmic reticulum stress and intestinal inflammation. Mucosal Immunol. 2010;3(1):11-6. Review.

2. MacDonald TT, Bell I, Monteleone G. The opposing roles of IL-21 and TGF $\beta 1$ in chronic inflammatory bowel disease. Biochem Soc Trans. 2011;39(4):1061-6. Review.

3. Pedersen J, Coskun M, Soendergaard C, Salem M, Nielsen OH. Inflammatory pathways of importance for management of inflammatory bowel disease. World J Gastroenterol. 2014;20(1):64-77. Review.

4. Baumgart DC, Sandborn WJ. Crohn's disease. Lancet. 2012;380(9853):1590-605. Review. Erratum in: Lancet. 2013;381(9862):204.

5. Høivik ML, Moum B, Solberg IC, Henriksen M, Cvancarova M, Bernklev T; IBSEN Group. Work disability in inflammatory bowel disease patients 10 years after disease onset: results from the IBSEN Study. Gut. 2013;62(3):368-75.

6. Herrinton LJ, Liu L, Lewis JD, Griffin PM, Allison J. Incidence and prevalence of inflammatory bowel disease in a Northern California managed care organization, 1996-2002. Am J Gastroenterol. 2008;103(8):1998-2006.

7. Lapidus A. Crohn's disease in Stockholm County during 1990-2001: an epidemiological update. World J Gastroenterol. 2006;12(1):75-81.

8. Victoria CR, Sassaki LY, Nunes HR. Incidence and prevalence rates of inflammatory bowel diseases, in Midwestern of São Paulo State, Brazil. Arq Gastroenterol. 2009;46(1):20-5.

9. M'Koma AE. Inflammatory bowel disease: an expanding global health problem. Clin Med Insights Gastroenterol. 2013;6:33-47. Review.

10. Loganes C, Pin A, Naviglio S, Girardelli M, Bianco AM, Martelossi S, et al. Altered pattern of tumor necrosis factor-alpha production in peripheral blood monocytes from Crohn's disease. World J Gastroenterol. 2016;22(41):9117-26.

11. Sartor RB. Genetics and environmental interactions shape the intestinal microbiome to promote inflammatory bowel disease versus mucosal homeostasis. Gastroenterology. 2010;139(6):1816-9. Figure 1, Genetic and environmental factors influence intestinal microbiota composition, which has an overall protective role in normal hosts, but containsan abnormal ratio of beneficial and aggressive bacterial species (dysbiosis) in Crohn's disease patients. This ratio of protective/ detrimental bacteria drivesactivated inflammatory cascades leading to Crohn's disease in genetically susceptible hosts and maintains mucosal homeostasis in normal subjects. p. 1817.

12. de Vos WM, de Vos EA. Role of the intestinal microbiome in health and disease: from correlation to causation. Nutr Rev. 2012;70 Suppl 1:S45-56. Review.

13. Loh G, Blaut M. Role of commensal gut bacteria in inflammatory bowel diseases. Gut Microbes. 2012;3(6):544-55. Review.

14. Scott KP, Antoine JM, Midtvedt T, van Hemert S. Manipulating the gut microbiota to maintain health and treat disease. Microb Ecol Health Dis. 2015;26:25877. 
15. Peyrin-Biroulet L, Gonzalez F, Dubuquoy L, Rousseaux C, Dubuquoy C, Decourcelle C, et al. Mesenteric fat as a source of $C$ reactive protein and as a target for bacterial translocation in Crohn's disease. Gut. 2012;61(1):78-85.

16. Sartor RB. Does Mycobacterium avium subspecies paratuberculosis cause Crohn's disease? Gut. 2005;54(7):896-8. Review.

17. Chiodini RJ, Van Kruiningen HJ, Thayer WR, Merkal RS, Coutu JA. Possible role of mycobacteria in inflammatory bowel disease. I. An unclassified Mycobacterium species isolated from patients with Crohn's disease. Dig Dis Sci. 1984;29(12):1073-9.

18. Pierce ES. Where are all the Mycobacterium avium subspecies paratuberculosis in patients with Crohn's disease? PLoS Pathog. 2009;5(3):e1000234. Review.

19. Bull TJ, McMinn EJ, Sidi-Boumedine K, Skull A, Durkin D, Neild P, et al. Detection and verification of Mycobacterium avium subsp. paratuberculosis in fresh ileocolonic mucosal biopsy specimens from individuals with and without Crohn's disease. J Clin Microbiol. 2003;41(7):291523.

20. Jostins L, Ripke S, Weersma RK, Duerr RH, McGovern DP, Hui KY, et al.; International IBD Genetics Consortium (IIBDGC). Host-microbe interactions have shaped the genetic architecture of inflammatory bowel disease. Nature. 2012;491(7422):119-24.

21. Feller M, Huwiler K, Stephan R, Altpeter E, Shang A, Furrer H, et al. Mycobacterium avium subspecies paratuberculosis and Crohn's disease: a systematic review and meta-analysis. Lancet Infect Dis. 2007;7(9):607-13. Review.

22. Behr MA, Kapur V. The evidence for Mycobacterium paratuberculosis in Crohn's disease. Curr Opin Gastroenterol. 2008;24(1):17-21. Review.

23. Hermon-Taylor J, Bull T. Crohn's disease caused by Mycobacterium avium subspecies paratuberculosis: a public health tragedy whose resolution is long overdue. J Med Microbiol. 2002;51(1):3-6.

24. Greenstein RJ. Is Crohn's disease caused by a mycobacterium? Comparisons with leprosy, tuberculosis, and Johne's disease. Lancet Infect Dis. 2003;3(8):507-14. Review.

25. Abubakar I, Myhill D, Aliyu SH, Hunter PR. Detection of Mycobacterium avium subspecies paratuberculosis from patients with Crohn's disease using nucleic acid-based techniques: a systematic review and meta-analysis. Inflamm Bowel Dis 2008;14:401-10.

26. Szewzyk U, Szewzyk R, Manz W, Schleifer KH. Microbiological safety of drinking water. Annu Rev Microbiol. 2000;54:81-127. Review.

27. Ellingson JL, Anderson JL, Koziczkowski JJ, Radcliff RP, Sloan SJ, Allen SE, et al. Detection of viable Mycobacterium avium subsp. paratuberculosis in retail pasteurized whole milk by two culture methods and PCR. J Food Prot. 2005;68(5):966-72.

28. Stabel JR, Bradner L, Robbe-Austerman S, Beitz DC. Clinical disease and stage of lactation influence shedding of Mycobacterium avium subspecies paratuberculosis into milk and colostrum of naturally infected dairy cows. J Dairy Sci. 2014;97(10):6296-304.

29. Alonso-Hearn M, Molina E, Geijo M, Vazquez P, Sevilla I, Garrido JM, et al. Isolation of Mycobacterium avium subsp. paratuberculosis from muscle tissue of naturally infected cattle. 
Foodborne Pathog Dis. 2009;6(4):513-8.

30. Barrett JC, Hansoul S, Nicolae DL, Cho JH, Duerr RH, Rioux JD, et al. Genome-wide association defines more than 30 distinct susceptibility loci for Crohn's disease. Nat Genet. 2008;40(8):955-62.

31. Over K, Crandall PG, O'Bryan CA, Ricke SC. Current perspectives on Mycobacterium avium subsp. paratuberculosis, Johne's disease, and Crohn's disease: a review. Crit Rev Microbiol. 2011;37(2):141-56. Review.

32. Kirkwood CD, Wagner J, Boniface K, Vaughan J, Michalski WP, Catto-Smith AG, et al. Mycobacterium avium subspecies paratuberculosis in children with early-onset Crohn's disease. Inflamm Bowel Dis. 2009;15(11):1643-55.

33. Tuci A, Tonon F, Castellani L, Sartini A, Roda G, Marocchi M, et al. Fecal detection of Mycobacterium avium paratuberculosis using the IS900 DNA sequence in Crohn's disease and ulcerative colitis patients and healthy subjects. Dig Dis Sci. 2011;56(10):2957-62.

34. Zamani S, Zali MR, Aghdaei HA, Sechi LA, Niegowska M, Caggiu E, et al. Mycobacterium avium subsp. paratuberculosis and associated risk factors for inflammatory bowel disease in Iranian patients. Gut Pathog. 2017;9:1.

35. Hermon-Taylor J. Mycobacterium avium subspecies paratuberculosis, Crohn's disease and the Doomsday scenario. Gut Pathog. 2009;1(1):15.

36. Sechi LA, Scanu AM, Molicotti P, Cannas S, Mura M, Dettori G, et al. Detection and Isolation of Mycobacterium avium subspecies paratuberculosis from intestinal mucosal biopsies of patients with and without Crohn's disease in Sardinia. Am J Gastroenterol. 2005;100(7):152936.

37. Ahluwalia B, Magnusson MK, Öhman L. Mucosal immune system of the gastrointestinal tract: maintaining balance between the good and the bad. Scand J Gastroenterol. 2017;52(11):1185-93.

38. Yadav V, Varum F, Bravo R, Furrer E, Bojic D, Basit AW. Inflammatory bowel disease: exploring gut pathophysiology for novel therapeutic targets. Transl Res. 2016;176:38-68. Review.

39. Coombes $\mathrm{JL}$, Maloy KJ. Control of intestinal homeostasis by regulatory T cells and dendritic cells. Semin Immunol. 2007;19(2):116-26. Review.

40. Tsuji NM, Kosaka A. Oral tolerance: intestinal homeostasis and antigen-specific regulatory $T$ cells. Trends Immunol. 2008;29(11):532-40. Review.

41. Hegazy AN, West NR, Stubbington MJ, Wendt E, Suijker KI, Datsi A, et al.; Oxford IBD Cohort Investigators. Circulating and Tissue-Resident CD4(+) T cells with reactivity to intestinal microbiota are abundant in healthy individuals and function is altered during inflammation. Gastroenterology. 2017;153(5):1320-37.

42. Nielsen $\mathrm{OH}$, Rask-Madsen J. Mediators of inflammation in chronic inflammatory bowel disease. Scand J Gastroenterol Suppl. 1996;216:149-59. Review.

43. Saiki T, Mitsuyama K, Toyonaga A, Ishida H, Tanikawa K. Detection of pro- and antiinflammatory cytokines in stools of patients with inflammatory bowel disease. Scand $\mathrm{J}$ Gastroenterol. 1998;33(6):616-22. 
44. Nielsen $\mathrm{OH}$, Gionchetti $\mathrm{P}$, Ainsworth M, Vainer B, Campieri M, Borregaard N, et al. Rectal dialysate and fecal concentrations of neutrophil gelatinase-associated lipocalin, interleukin-8, and tumor necrosis factor-alpha in ulcerative colitis. Am J Gastroenterol. 1999;94(10):2923-8.

45. Ordás I, Mould DR, Feagan BG, Sandborn WJ. Anti-TNF monoclonal antibodies in inflammatory bowel disease: pharmacokinetics-based dosing paradigms. Clin Pharmacol Ther. 2012;91(4):635-46. Review.

46. Pan MG, Xiong J, Copeland NG, Gilbert DJ, Jenkins NA, Goeddel DV. Sequence, genomic organization, and chromosome localization of the mouse TRADD gene. J Inflamm. 19951996;46(3):168-75.

47. Yamamoto-Furushoa JK, Bosques-Padilla F, de-Paula J, Galiano MT, Ibanez P, Juliao F, et al. Diagnóstico y tratamiento de la enfermedad inflamatoria intestinal: Primer Consenso Latinoamericano de la Pan American Crohn's and Colitis Organisation. Rev. Gastroenterol Méx. 2017;82(1):46-84.

48. Gomollón F, Dignass A, Annese V, Tilg H, Van Assche G, Lindsay JO, et al.; on behalf of ECC. 3rd European Evidence-based Consensus on the Diagnosis and Management of Crohn's Disease 2016: Part 1: Diagnosis and Medical Management, J Crohn's Colitis. 2017; 11(1):3-25.

49. Sipponen T, Kolho KL. Fecal calprotectin in diagnosis and clinical assessment of inflammatory bowel disease. Scand J Gastroenterol. 2015;50(1):74-80. Review.

50. Tibble JA, Sigthorsson G, Foster R, Forgacs I, Bjarnason I. Use of surrogate markers of inflammation and Rome criteria to distinguish organic from nonorganic intestinal disease. Gastroenterology. 2002;123(2):450-60.

51. Tibble J, Teahon K, Thjodleifsson B, Roseth A, Sigthorsson G, Bridger S, et al. A simple method for assessing intestinal inflammation in Crohn's disease. Gut. 2000;47(4):506-13.

52. Colombel JF, Sandborn WJ, Rutgeerts P, Enns R, Hanauer SB, Panaccione R, et al. Adalimumab for maintenance of clinical response and remission in patients with Crohn's disease: the CHARM trial. Gastroenterology. 2007;132(1):52-65.

53. Hanauer SB, Feagan BG, Lichtenstein GR, Mayer LF, Schreiber S, Colombel JF, et al.; ACCENT I Study Group. Maintenance infliximab for Crohn's disease: the ACCENT I randomised trial. Lancet. 2002;359(9317):1541-9.

54. Sands BE, Anderson FH, Bernstein CN, Chey WY, Feagan BG, Fedorak RN, et al. Infliximab maintenance therapy for fistulizing Crohn's disease. N Engl J Med. 2004;350(9):87685.

55. Sandborn WJ, Hanauer SB, Rutgeerts P, Fedorak RN, Lukas M, MacIntosh DG, et al. Adalimumab for maintenance treatment of Crohn's disease: results of the CLASSIC II trial. Gut. 2007;56(9):1232-9.

56. Vavricka SR, Spasojevic M, Rogler G, Schoepfer AM, Seibold F, Borovicka J, et al.; Swiss IBDnet. Long-term efficacy and safety of certolizumab pegol in an unselected Crohn's disease population: the FACTS III Survey. Dig Dis. 2017;35(5):423-32.

57. Ma C, Huang V, Fedorak DK, Kroeker KI, Dieleman LA, Halloran BP, et al. Crohn's disease outpatients treated with adalimumab have an earlier secondary loss of response and requirement for dose escalation compared to infliximab: a real life cohort study. J Crohns Colitis. 
2014;8(11):1454-63.

58. Bartelds GM, Krieckaert CL, Nurmohamed MT, van Schouwenburg PA, Lems WF, Twisk JW, et al. Development of antidrug antibodies against adalimumab and association with disease activity and treatment failure during long-term follow-up. JAMA. 2011;305(14):1460-8.

59. Steenholdt C, Bendtzen K, Brynskov J, Thomsen $\oslash \varnothing$, Ainsworth MA. Cut-off levels and diagnostic accuracy of infliximab trough levels and anti-infliximab antibodies in Crohn's disease. Scand J Gastroenterol. 2011;46(3):310-8.

60. Pariente B, Pineton de Chambrun G, Krzysiek R, Desroches M, Louis G, De Cassan C, et al. Trough levels and antibodies to infliximab may not predict response to intensification of infliximab therapy in patients with inflammatory bowel disease. Inflamm Bowel Dis. 2012;18(7):1199-206.

61. Vermeire S, Noman M, Van Assche G, Baert F, D'Haens G, Rutgeerts P. Effectiveness of concomitant immunosuppressive therapy in suppressing the formation of antibodies to infliximab in Crohn's disease. Gut. 2007;56(9):1226-31.

62. Levesque BG, Loftus EV Jr. Initiating azathioprine for Crohn's disease. Clin Gastroenterol Hepatol. 2012;10(5):460-5.

63. Sokumbi O, Wetter DA, Makol A, Warrington KJ. Vasculitis associated with tumor necrosis factor- $\alpha$ inhibitors. Mayo Clin Proc. 2012;87(8):739-45.

64. Beigel F, Jürgens M, Filik L, Bader L, Lück C, Göke B, et al. Severe Legionella pneumophila pneumonia following infliximab therapy in a patient with Crohn's disease. Inflamm Bowel Dis. 2009;15(8):1240-4.

65. Dasari BV, McBrearty A, Gardiner K. Immunosuppression in patients with Crohn's disease and neoplasia: an ongoing clinical dilemma. Dis Colon Rectum. 2012;55(9):1008-11.

66. Marinaki AM, Ansari A, Duley JA, Arenas M, Sumi S, Lewis CM, et al. Adverse drug reactions to azathioprine therapy are associated with polymorphism in the gene encoding inosine triphosphate pyrophosphatase (ITPase). Pharmacogenetics. 2004;14(3):181-7.

67. Alcedo KP, Thanigachalam S, Naser SA. RHB-104 triple antibiotics combination in culture is bactericidal and should be effective for treatment of Crohn's disease associated with Mycobacterium paratuberculosis. Gut Pathog. 2016;8:32.

68. Qasem A, Naser AE, Naser SA. The alternate effects of anti-TNFo therapeutics and their role in mycobacterial granulomatous infection in Crohn's disease. Expert Rev Anti Infect Ther. 2017;15(7):637-43.

69. Selby WS. Mycobacterium avium subspecies paratuberculosis bacteraemia in patients with inflammatory bowel disease. Lancet. 2004;364(9439):1013-4.

70. Hedin CR, Stagg AJ, Whelan K, Lindsay JO. Family studies in Crohn's disease: new horizons in understanding disease pathogenesis, risk and prevention. Gut. 2012;61(2):311-8. Review.

71. Sipponen T, Savilahti E, Kolho KL, Nuutinen H, Turunen U, Färkkilä M. Crohn's disease activity assessed by fecal calprotectin and lactoferrin: correlation with Crohn's disease activity index and endoscopic findings. Inflamm Bowel Dis. 2008;14(1):40-6. 
72. Molodecky NA, Soon IS, Rabi DM, Ghali WA, Ferris M, Chernoff G, et al. Increasing incidence and prevalence of the inflammatory bowel diseases with time, based on systematic review. Gastroenterology. 2012;142(1):46-54.e42; quiz e30. Review.

73. Henriksen M, Jahnsen J, Lygren I, Stray N, Sauar J, Vatn MH, et al.; IBSEN Study Group. C-reactive protein: a predictive factor and marker of inflammation in inflammatory bowel disease. Results from a prospective population-based study. Gut. 2008;57(11):1518-23.

74. Cappello M, Morreale GC. The role of laboratory tests in Crohn's Disease. Clin Med Insights Gastroenterol. 2016;9:51-62. Review.

75. Costa F, Mumolo MG, Bellini M, Romano MR, Ceccarelli L, Arpe P, et al. Role of faecal calprotectin as non-invasive marker of intestinal inflammation. Dig Liver Dis. 2003;35(9):642-7.

76. Kotze LM, Nisihara RM, Marion SB, Cavassani MF, Kotze PG. FECAL CALPROTECTIN: levels for the ethiological diagnosis in Brazilian patients with gastrointestinal symptoms. Arq Gastroenterol. 2015;52(1):50-4.

77. Carrière J, Darfeuille-Michaud A, Nguyen HT. Infectious etiopathogenesis of Crohn's disease. World J Gastroenterol. 2014;20(34):12102-17. Review.

78. O'Mahony J, Hill C. Rapid real-time PCR assay for detection and quantitation of Mycobacterium avium subsp. paratuberculosis DNA in artificially contaminated milk. Appl Environ Microbiol. 2004;70(8):4561-8.

79. Naser SA, Ghobrial G, Romero C, Valentine JF. Culture of Mycobacterium avium subspecies paratuberculosis from the blood of patients with Crohn's disease. Lancet. 2004;364(9439):1039-44.

80. Shin SJ, Collins MT. Thiopurine drugs azathioprine and 6-mercaptopurine inhibit Mycobacterium paratuberculosis growth in vitro. Antimicrob Agents Chemother. 2008;52(2):41826. Erratum in: Antimicrob Agents Chemother. 2008;52(3):1208.

81. Best WR, Becktel JM, Singleton JW, Kern F Jr. Development of a Crohn's disease activity index. National Cooperative Crohn's Disease Study. Gastroenterology. 1976;70(3):439-44. 


\begin{abstract}
Introduction: A long time is looking evidence of a causal association of Mycobacterium avium paratuberculosis and Crohn's disease, but this association is still unclear. Many studies have shown a positive correlation between disease and M. avium subsp. paratuberculosis infection, however unrelated these findings with the characteristics of the population studied. Purpose: We investigated the presence of $M$. avium subsp. paratuberculosis DNA fragment in stool from Crohn's disease patients and from healthy controls and correlate with clinical features. Methods: Stool and blood samples from 52 Chron's Disease patients and 43 from control patients were collected. Clinical tests were performed and DNA was extracted from stool samples. Mycobacterium avium subsp. paratuberculosis presence was verified with a specific Real-Time PCR method. Results: There was no evidence of Mycobacterium avium subsp. paratuberculosis in the stool samples. Median faecal calprotectin was significantly increased in Crohn's disease subjects $(p<0.001)$. Most individuals with Crohn's disease, had an established therapeutic regimen (88.5\%) and being on treatment for more than a year. Conclusions: The characteristics of the studied population could interfere in the analysis of presence of Mycobacterium avium subsp. paratuberculosis in patients with Chron's Disease. Specific recruitment criteria are required for this analysis.
\end{abstract}

